\title{
DA DOR SOLITÁRIA E DAS LÁGRIMAS QUE NÃO SE MOSTRA: A CRIMINALIZAÇÃO DO ABORTO COMO PUNIÇÃO DA SEXUALIDADE DA MULHER
}

\author{
THE LONELY PAIN AND THE NOT REVEALED TEARS: ABORTION CRIME AS A \\ PUNISHMENT OF THE WOMAN'S SEXUALITY
}

\begin{abstract}
Emmanuella Magro Denora
Mestra em Ciência Jurídica pela Universidade Estadual do Norte do Paraná (UENP 2018); bacharel em Direito pela Universidade Estadual de Londrina (UEL - 2008); Advogada; Professora de Direito Constitucional, de Direito Processual Penal e Direito Penal a nível de graduação e Pós-Graduação Latu Senso. Pesquisadora em Feminismo(s) e Direito. E-mail: denora.adv@gmail.com

Fernando de Brito Alves Socii in Collatione Juridica Conimbrigensi pelo IGC da Faculdade de Direito da
Universidade de Coimbra. Professor Doutor Adjunto da Universidade Estadual do Norte
do Paraná - UENP. Coordenador do Programa de Mestrado e Doutorado em Ciência
Jurídica da UENP. Professor das Faculdades Integradas de Ourinhos - SP. Advogado.
E-mail: fernandobrito@uenp.edu.br
\end{abstract}

Recebido em: 08/04/2018

Aprovado em: 20/08/2018

RESUMO: Considerando que, não obstante a legislação criminalizante do aborto, as mulheres ainda o praticam, objetiva-se tecer considerações sobre a possibilidade e cabimento da legalização do ato, com finalidade protetiva da saúde reprodutiva das mulheres. Para tanto, através do método hipotético-dedutivo, selecionou-se dois eixos argumentativos, o primeiro quanto ao uso político de direitos das mulheres e do controle de seus corpos e de sua sexualidade postas numa estrutura misógina, e o segundo quanto aos efeitos diretos e indiretos que a legislação penal promove. Ainda, analisou-se a possibilidade constitucional da legalização do aborto através das manifestações proferidas no HC 124.306/RJ por Luis Roberto Barroso, Ministro do Supremo Tribunal Federal, apresentando algumas considerações pertinentes ao tema. Concluiu-se que a legislação em vigência tem propósito não declarado de segregação das mulheres, cuja situação se agrava por questões de classe e raça, como forma de controle e de punição de sua sexualidade, e que legalizar o aborto seria medida de cidadania para considerar a mulher em sua esfera de liberdade e escolha.

Palavras-Chave: Legalização do Aborto; Direito das Mulheres; Direito e Feminismo; Criminologia Feminista.

ABSTRACT: Considering that, despite the criminal law of abortion, women still practice it, in this paper is intended to make considerations about the possibility and adequacy in the legalization of the act, with a protective purpose of women's reproductive health. To do so, through the hypothetical-deductive method, two argumentative axes were selected, the first regarding the political use of women's rights and the control of their bodies and their sexuality placed in a misogynistic structure, and the second regarding the direct and indirect bad effects 
that the criminal legislation promotes. Also, the constitutional possibility of legalizing abortion was analyzed through the manifestations given in HC 124.306 / RJ by Luis Roberto Barroso, Minister of the Federal Supreme Court, presenting some pertinent considerations to the topic. It was concluded that the legislation in force has an undeclared purpose of segregating women, whose situation is aggravated by class and race, as a form of control and punishment of their sexuality, and that legalizing abortion would be a citizen's measure to consider the woman in her sphere of freedom and choice.

Keywords: Legal Abortion; Women's Rights; Law and Feminism; Feminist Criminology.

SUMÁRIO: 1 Introdução. 2 Precisamos falar sobre aborto; 2.1 Mas o que é, afinal, aborto?; 2.1.1 Aborto na legislação brasileira. 3 O que significa o HC 124.306/RJ. Conclusões. Referências

\section{INTRODUÇÃO}

Tratar de aborto seja talvez tratar de tema tão antigo quanto a própria noção de humanidade - desde que os seres humanos tomaram consciência sobre se reproduzir enquanto espécie, já se revela as possibilidades de haver em algum ponto uma gestação indesejada, pelo motivo que for. Não obstante sua antiguidade, ainda é tema considerado tabu por muitas comunidades, inclusive a política. Apto a definir eleições e campanhas, e sempre que trazido à tona tende a provocar reações de grupos específicos já conhecidos. Os debates se polarizam entre as bancadas religiosas e afins, mais conservadoras, e os mais progressistas, vinculados a movimentos sociais feministas e de gênero, num cabo de guerra ideológico que tende a nunca se satisfazer por não promover um debate honesto com a sociedade, apresentando racionalmente as motivações de um Estado laico e radicalizando as premissas democráticas.

Este texto vem vinculado aos debates progressistas, que não objetivam o incentivo a abortos, mas uma discussão técnica de uma realidade que deve ser tratada de modo igualmente técnico e honesto diante do problema: as mulheres abortam independentemente de haver uma legislação proibitiva penal. Haver tal legislação apenas impede que as mulheres que decidam (pelas razões que forem) ao procedimento o façam de forma segura, implicando em riscos a saúde reprodutiva das mesmas bem como suas próprias vidas. Desde essa premissa social constatada, busca-se uma resposta judicial adequada através de uma visão inclusiva e democrática de intervenção mínima estatal nas liberdades individuais.

Tal discussão, de forma científica e comprometida com a realidade dos fatos, faz-se necessária sempre que há demonstrações de recrudescimento do Estado em assuntos de minorias, evidenciando um déficit democrático, cuja resposta a problemas sociais tendem a ser dadas através do Direito Penal - o que historicamente gera um novo problema social e a manutenção do problema em tese combatido por ele.

Assim, objetiva-se percorrer os caminhos desse debate contrapondo os argumentos apresentados. Para tanto, utiliza-se o método hipotético-dedutivo, considerando-se hibridamente duas incidências que se compreendeu como principais ao formato (e que nelas orbitam questões adjacentes que as fomentam) para a construção da proposta: (a) o corpo da mulher e seu lugar político e social numa estrutura circunstancialmente misógina e a forma de controle criminal dessa "minoria" exercido através da legislação; e (b) no que implica a tutela jurídica criminal proibitiva do aborto nos moldes da legislação brasileira em vigência, considerando a realidade socioeconômica (im)posta às mulheres que recorrem ao aborto, diante das poucas políticas públicas desenvolvidas a respeito da saúde da mulher, analisadas e complementadas pelas considerações postas da decisão do Habeas Corpus 124.306/RJ proferido pelo Ministro do Supremo Tribunal Federal, o também professor Luis Roberto Barroso. 
Quando se criminaliza o aborto o Estado brasileiro opta por uma resposta penal ao assunto, fazendo assim uma escolha política que engessa demais medidas de mitigação do tema, necessariamente implicando no surgimento de um "mercado" paralelo a respeito, que envolve precarização de serviços médicos e sanitários - posto a ausência de controle estatal - , utilização de fármacos de procedência desconhecida, bem como riscos de mutilação, infecções e inflamações (corriqueiros nos casos de auto aborto caseiro). Ainda que não haja o encarceramento massivo de mulheres que praticam o aborto, a existência normativa criminal coloca a prática sob a vigilância estatal, necessariamente impondo às mulheres biologicamente identificadas uma punição - seja direta ou indireta - pelo exercício de sua sexualidade. Deste modo, (re)discutir sua alocação sob a égide criminal importa para se pensar caminhos mais suaves a serem trilhados nesse diapasão.

\section{PRECISAMOS FALAR SOBRE ABORTO}

Numa democracia é importante que exista a possibilidade de discussão de pautas consideradas polêmicas. De que seja possível falar-se, abordar-se, questionar-se e repensar-se sobre temas, como ato de manifestação cidadã - ainda que controversos por natureza dentro de uma estrutura posta. Não se convém dogmas, sob pena de a desvirtuarmos como tal - ainda que haja limitações constitucionais e humanitárias para alterações legislativas no que tange à restrição de direitos fundamentais, acertadamente, com o escopo de evitar-se que uma "maioria" abafe ou anule direitos fundamentais de "minorias" e o próprio exercício democrático. Numa democracia, pode-se haver temas que não sejam consenso, e que ainda assim impliquem numa resposta constitucional adequada para tanto respeitando a diversidade e diversificação que a própria ideia de ser-humano concebe em sua individualização, e a compreensão do papel da razão pública.

E quando se fala sobre aborto indubitavelmente se está pisando em local sensível, revestido de dogmas de fé e tabus morais, mas que também possui tutela jurídico-legal, e que portanto, passa a ser assunto de Estado. O resultado desse tratamento indisposto e "cheio de dedos" em relação ao aborto é não se propor a (re)pensar seu instituto criminalizador: porque falar sobre aborto desperta paixões cegas no discurso, responsabilização feminina e, na forma como está posta no Brasil, um desamparo quase pleno à mulher que o faz - mesmo nas hipóteses permitidas em lei, como se abordará.

Trazer à discussão o tema da legalização do aborto no Brasil tende a envolver opiniões bastante viscerais e polarizadas de determinados grupos sociais, até mesmo pelos interesses políticos havidos, e em regra vinculados a religiosos em sua maioria de matrizes cristãs (católicos e evangélicos, sobretudo). Estas mesmas opiniões tendem igualmente a vir desacompanhadas de análises sócio jurídicas mais complexas (uma vez que tutelado pelo Direito em sua vertente mais violenta, o Direito Penal), e assim o procedem porque encontram seu fundamento na fé, e contra a fé não há cientificidade e racionalidade que se sustente em suas respostas e soluções na ordem do imaginário e mágico. O corpo social brasileiro tem uma resistência ao tema, previsivelmente pela falta de debate e discussão. As vozes que ganham eco e que possuem espaço significativo tendem a utilizar-se de argumentos da ordem do religioso e da moral, sobretudo pela representatividade política que tais grupos ocupam nas estâncias de poderes - seja Executivo, Legislativo ou Judiciário, em todos os níveis do pacto republicano (o que não implica dizer que não haja resistência aos conservadores).

Implica em responsabilização da mulher, porque, assunto complexo que é, ao final e ao cabo delega a ela que se decida sobre bens jurídicos muito caros e cujas implicações sociais, morais e jurídicas podem gerar novos problemas nessa mesma ordem e que oneram sua condição de cidadania. E, por fim, se trata de uma decisão solitária das mulheres, por vezes abandonadas (na esfera privada) por seus companheiros, familiares e oprimida (na esfera pública) pelo Estado em todas as incidências: proíbe-se o aborto com sanção criminal (que acaso realizado, implica no 
honesto receio e devida cautela ao buscar os serviços de saúde em eventuais complicações), tutelando o corpo da mulher como um objeto reprodutor a serviço de si, causando o efeito da maternidade compulsória, que obriga a gestação e seu ônus (um bebê necessariamente implica em transformações no corpo da mulher e em sua realidade socioeconômica) mas que desampara e pouco auxilia em informações, serviços de pré-natal e proteção sócio jurídica à mulher que se torna mãe.

Licença maternidade desigual para homens e mulheres, gerando desigualdade de tratamento e protelação/estagnação/dispensa na carreira destas; pouca proteção trabalhista à mulher que se torna mãe; ausência de creches e escolas em período integral; oportunidades diluídas na carreira profissional da mulher; são exemplificativamente ausências de políticas públicas que necessariamente oneram a mulher no exercício de maternidade [compulsória], cujo recorte de classe e raça torna-se um fator ainda mais agressivo às mães desses grupos ${ }^{1}$.

Fato é que há mulheres adoecendo e/ou morrendo em razão de abortos inseguros e precários, porque seus corpos não lhe pertencem, são cidadãs pela metade, o que é resultado direto da tutela criminal sobre o assunto, e ainda que tenham havido num passado próximo alguns poucos avanços paliativos em relação ao tema, há um conjunto de fatores que denotam a tendência ao recrudescimento no tratamento do assunto. Luis Felipe Miguel (2016, p. 57), leciona que

A soberania sobre si mesmo é um direito fundante da possibilidade de ação autônoma da arena política. Mas permanece uma grave assimetria entre homens e mulheres, gerada por aquilo que podemos chamar de gravidez compulsória, que representa uma limitação potencial permanente à soberania das mulheres sobre si mesmas. Então o cidadão, isto é, o homem, ingressa na esfera política dotado de soberania sobre si mesmo, mas para a mulher, tal soberania é condicional. Sob determinadas circunstâncias, ela deixa de exercer arbítrio sobre seu próprio corpo e se torna um instrumento para um fim alheio. Nesse processo ocorre uma inversão: em vez da sociedade ficar com a obrigação de garantir as condições para que as mulheres possam levar a cabo gestações livremente decididas, a gravidez passa ser uma obrigação perante a sociedade. [Grifos do autor].

Numa análise do cenário político sobre o assunto, se por um lado os movimentos feministas optaram pela estratégia de retirada do aborto como pauta prioritária, priorizando outras tidas como mais urgentes em determinados contextos, também nessas ações tiveram reduzidas suas possibilidades de liderança no debate - desde a evitação de tratamento constitucional para o aborto em 1988 ao recuo nas eleições presidenciais de 2010 - sobre o tema; por outro lado o aborto ganhou prioridade entre grupos religiosos, em especial a partir dos anos $1990^{2}$, passando a

\footnotetext{
${ }^{1}$ De acordo com a pesquisa "Licença maternidade e suas consequências no mercado de trabalho do Brasil", da Escola Brasileira de Economia e Finanças da Fundação Getúlio Vargas (FGV), 48\% das mães são demitidas de seus trabalhos nos primeiros 12 meses após a licença maternidade. Os fatores considerados como preponderantes são a tradicional responsabilização da mulher pelos cuidados das crianças no período, e diferente divisão de tarefas com seus parceiros. Disponível em < https://brasil.elpais.com/brasil/2017/08/14/politica/1502721247_786237.html > ; https://estilo.uol.com.br/gravidez-e-filhos/noticias/redacao/2017/08/28/48-das-maes-ficam-desempregadas-noprimeiro-ano-apos-o-parto.htm > Acesso em 15 de Outubro de 2017. Outra pesquisa, divulgada pela BBC e publicada em vários canais de imprensa, mostra que as mães têm suas carreiras prejudicadas - falta de creches, instabilidade no setor privado, bem como impossibilidades de crescimento na carreira, além de demissão. Por outro lado, os pais têm maiores oportunidades de crescimento.Disponível em < https://g1.globo.com/economia/concursose-emprego/noticia/por-que-ter-filhos-prejudica-mulheres-e-favorece-pais-no-mercado-de-trabalho.ghtml > Acesso em 09 de Fevereiro de 2018.

${ }^{2}$ Sobre as discussões sobre aborto do Legislativo: "a distribuição dos discursos ao longo do tempo é bastante irregular [...]. Entre 1991 e 1999, foram pronunciados 325 discursos sobre aborto no plenário da Câmara dos Deputados, com um pico de 119 pronunciamentos em 1997, quando os parlamentares contrários ao direito ao aborto conseguiram evitar que o Projeto de Lei 20/1991, que regulamentava o atendimento às mulheres no caso de aborto
}

Revista de Direito Brasileira | São Paulo, SP | v. 20 | n. 8 | p. 378-407 |Mai./Ago. 2018 
ser uma das temáticas centrais na atuação destes grupos no Legislativo, e sendo usada por tais grupos como barganha ao "negociar" com o Executivo - aqueles descobriram que é possível usar direitos individuais e ataques a minorias como moeda de troca a outras temáticas e interesses, colocando à disposição direitos - de mulheres e homossexuais, principalmente, que simbolizam a ofensiva - fundamentais destes grupos a fim de mitigação e uso político (BIROLI; MIGUEL, 2016, p.11.).

Aborto, e consequentemente o corpo da mulher, passa a ter valor de escambo político e com finalidade de disputas de poder em outras pautas por homens brancos, ricos e autodeclarados como heterossexuais.

Os oradores ${ }^{[3]}$ são, quase todos, homens. A presença feminina é particularmente baixa no parlamento brasileiro. De acordo com os dados da Inter-Parlamentary Union, o país ocupa a penúltima posição na América latina, em quantidade de mulheres na câmara baixa. No período sob análise [1991-2014], a participação feminina na Câmara dos Deputados oscilou em torno dos $8 \%$. Não é surpresa, portanto, que mesmo com as mulheres se pronunciando mais, dado o interesse específico da temática para elas, o debate seja dominado pelos homens: eles são os oradores de $86,4 \%$ dos discursos da amostra. O quadro fica pior quando se constata que a questão do aborto é o foco central de $61,7 \%$ dos discursos deles, mas apenas 49,2\% dos discursos delas. Isto é, quando as mulheres intervêm na discussão, o aborto costuma ser apenas um tema, entre outros, que elas abordam no mesmo pronunciamento. (MIGUEL; BIROLI; MARIANO, 2016, p. 136)

São os corpos das minorias que sofrem em regimes de austeridade, em que as camadas de base - e nesse caso o recorte de classe e raça passa a ser um componente essencial na discussão sobre o aborto - são usadas em tais manobras, vide Projeto de Emenda Constitucional $181 / 2015^{4}$. O uso político do aborto como negociata eleitoreira não é novidade, mas escancarouse nas eleições de 2010, em que a disputa pelo voto religioso (sobretudo o evangélico pentecostal e católico) demonstrou que essa parcela do eleitorado é numericamente significativa. Denise Maria Mantovani (2016, p. 189-216), ao analisar o papel do jornalismo na definição dos discursos conservadores nesse caso, relata que a polêmica havida sobre aborto como principal

previsto por lei, na rede pública de saúde, fosse enviado ao Senado. A derrota do projeto suscitou fortes reações dos movimentos feministas [...] levando à conquista da norma técnica do Ministério da Saúde regulamentando o atendimento. [...] Apenas dez anos depois o debate voltaria a uma frequência semelhante. Foram 97 discursos em 2007 e 112 em 2008, as duas maiores quantidades de pronunciamentos anuais sobre o tema, atrás apenas de 1997. [...] A Frente Parlamentar Evangélica atuava com essa denominação desde 2003, e em 2007 estavam tomadas outras três frentes parlamentares com o objetivo de obstruir avanços no direito ao aborto ou de fazer retroceder a legislação, reduzindo o número de casos previstos para o abortamento legal ou dificultando o acesso das mulheres a esse direito: a Frente Parlamentar Contra a Legalização do Aborto, a Frente Parlamentar da Família e Apoio à Vida e a Frente Parlamentar Mista em Defesa da Vida - Contra o Aborto. Essas frentes reagiam a iniciativas favoráveis ao direito ao aborto no âmbito Executivo, como a Norma Técnica de "Atenção Humanizada ao abortamento", de 2005, que determinava o atendimento nos hospitais públicos a mulheres que sofreram violência sexual e desejavam realizar um aborto mesmo quando não houvesse boletim de ocorrência [...] e do Judiciário, com a possibilidade de aprovação da ADPF n. 54, apresentada ao STF em 2004 [...]” (MIGUEL; BIROLI; MARIANO, 2016, p.138-139)

${ }^{3}$ NarealizaçãodoestudoemcitaçãoqueanalisaodebatesobreabortonaCâmaradosDeputados, osautoresleramecategorizaramtodososdiscursossobreotemanoperíodode 1991 a 2014, contendoasseguintespalavraschave: "aborto" "abortamento" “interrupçãovoluntáriadagestação" ou "interrupçãovoluntáriadagravidez". Identificou-seaotodo 939 discursos, sendoutilizados 915 destes, umavezqueem 24 apalavra "aborto" foiusadacommetáforaouencaminhamentosdevotação. 915 discursoscorrespondeamenosde $1 \%$ dototalestimadodediscursosnoplenáriodoperíodoemanálise (MIGUEL; BIROLI; MARIANO, 2016, p. 135).

4 Para a integralidade e acompanhamento do Projeto de Emenda, disponível em < http://www.camara.gov.br/proposicoesWeb/fichadetramitacao?idProposicao=2075449 > Acesso em 12de Novembro de 2017 . 
assunto na cobertura eleitoral não promoveu uma discussão efetiva sobre a descriminalização ou legalização do direito ao aborto no Brasil, muito menos um debate em torno do direito autônomo das mulheres sobre seu corpo, aspecto central ao se discutir a laicidade do Estado ou o aprimoramento de valores ampliativos de igualdade entre sujeitos (homens e mulheres) nas democracias liberais.

Em sua pesquisa, após apreciação numérica e de dados, constatou que a maior parte das fontes que ocupou os noticiários no período de julho a outubro de 2010 eram vinculadas a segmentos religiosos, o que transformou a disputa presidencial num instrumento de disputa eleitoral por setores do campo religioso e político, cuja cobertura jornalística fora estrategicamente orientada a ter o aborto como centro dessa disputa com o escopo do diferencial dos votos religiosos, quantitativamente significativo para definição de quem ocuparia o cargo. Essa postura dos jornais, que não promoveu o debate equilibrado do tema, reforçou uma cobertura que colaborou para endossar posicionamentos conservadores determinados pelas igrejas em seu movimento de persuasão aos fiéis contra o voto "naqueles que defendem o aborto". O campo jornalístico é esfera importante na construção da realidade e na forma como os indivíduos organizam os acontecimentos registrados em seu cotidiano, não sendo um espaço neutro de mera narrativa, posto sua influência em predispor o cidadão e a cidadã a determinadas preferências partidárias ou posicionamentos ideológicos (MANTOVANI, 2016, p. 190-191).

$\mathrm{O}$ aborto tomou forma na disputa eleitoral já a partir do primeiro turno, através de ferramentas de comunicação digital e redes sociais, advinda de mobilização de setores religiosos que desestimulavam o voto em candidatos que se posicionavam ou se posicionaram em outros momentos a favor da legalização do aborto, bem como do casamento homoafetivo e adoção por casais de mesmo sexo, reformulando a "família tradicional brasileira". Tal mobilização foi ignorada a priori pela grande mídia convencional, que optou pela exploração de escândalos políticos em administrações anteriores dos candidatos e/ou seus partidos. Ao analisar as quedas das intenções de voto na então candidata Dilma Roussef (PT) no primeiro turno, percebeu-se que os fatores numéricos em escândalos políticos se mantinham estáveis, porém, a polêmica do aborto causou maiores danos, ao observar a queda de intenção de votos nas comunidades católicas e evangélicas pentecostais, tornando então tal temática um assunto "público" ao ser validado pelas mídias tradicionais, que passaram e repercutir o tema no segundo turno (MANTOVANI, 2016, p. 192-200).

Tal mudança comportamental da cobertura jornalística indica que o agendamento do tema ocorreu por fatores exógenos aos seus controles e filtros, e que não obstante tal orientação de pauta ter sido criticada pelos editoriais e opinativos respectivos, por centrar o debate presidencial em discussões conservadoras sobre o aborto, em vez de reafirmar valores do processo democrático e amadurecimento do eleitorado, os mesmos veículos jornalísticos optaram pelo "não debate" efetivo ao não aprofundar o assunto, concentrando a cobertura nas estratégias e contradições dos candidatos referente ao posicionamento pessoal, impondo necessariamente uma confusão entre fé e direito como fundamento aos eleitores, enquadrando o aborto como questão moral e não possibilitando o debate como questão de direito, além de reforçar um discurso antiabortista ao ceder espaços praticamente exclusivos aos religiosos - posto que era o voto deles que estava jogo (MANTOVANI, 2016, p.193-205).

Como explica, os discursos socialmente hegemônicos são reproduzidos como portadores de valores "universais" e os contra discursos são muitas vezes silenciados ou não se tornam públicos, a não ser como "estereótipos verbais". O debate estereotipado ou mesmo a tímida presença de vozes em defesa do direito ao aborto e de sua descriminalização, contrastando com a grande presença de agentes do campo religioso e do campo político agindo como sujeitos definidores dos discursos dominantes, contrários ao aborto, são exemplos de uma narrativa legitimadora de constrangimentos estruturais de gênero (MANTOVANI, 2016, p. 205). Complementa, identificando que 
Os enquadramentos noticiosos envolvendo a descriminalização do aborto nas eleições de 2010 estavam concentrados em dois eixos centrais: um, de ordem política, em que predominavam as ênfases nas "estratégias eleitorais" dos candidatos para conquistar o voto dos eleitores religiosos e para uma postura "oportunista" de mudança de posicionamento, atributo principalmente vinculado à candidata Dilma Roussef $(\mathrm{PT})$. O outro eixo estava voltado para a ênfase aos valores religiosos com destaque para a condenação do aborto por ser uma "prática contrária aos princípios da igreja" e na oposição entre o aborto e a "defesa da vida e da família". (MANTOVANI, 2016, p. 206)

Nesse contexto, fica assaz evidente que o direcionamento dado e a opção pela abordagem como fora, buscou evitar a resolução do mérito e a problematização do aborto num espaço de cidadania, em que a seletividade midiática estabeleceu uma agenda pública conservadora - cujos efeitos tem-se sentido de modo muito claro em 2017 e 2018 em continuidade - e mostrou que o contexto de politização do religioso assume relevância numérica e expressiva apta a determinação de pautas excludentes, e neste caso em específico, não somente não se propiciou um debate sobre o assunto, como reiterou-se e reforçou-se significações de gênero que "submeteram a discussão sobre a temática da mulher, como o direito sobre seu corpo, a posições conservadoras, ao moralismo religioso e a valores masculinos, reproduzindo discursos que naturalizam hierarquias e desigualdades de gênero" (MANTOVANI, 2016, p. 213), revelando-se muito eficiente o poder politico na dominação dos corpos das minorias: os setores mais progressistas, com a escusa de evitar retrocessos ao pouco que se avançou, aceita negociar a estagnação a fim de não haver uma segregação ainda mais incisiva nesses aspectos em razão da presença religiosa na política e do uso da razão pública nessas pautas.

A estratégia do uso do aborto como chantagem política em campanha reapareceu em 2014, que, de acordo com Luis Felipe Miguel, Flávia Biroli e Rayani Mariano (2016), além da pauta em campanhas semelhantemente teve atenção do Congresso, em pronunciamentos e audiências públicas das comissões parlamentares de projetos de lei, e quem as trouxe em pauta foram majoritariamente grupos religiosos (católicos, evangélicos e também espíritas) - e não necessariamente partidos com siglas pontuais - revelando a ofensiva retrógrada e seu perfil relacionado à religião, cuja pesquisa em dados mostra que, se por um lado houve crescimento expressivo de tais grupos, em oposição minguou-se posicionamentos abertamente favoráveis a legalização. Destes últimos, tem-se que em seus argumentos o viés destacado é sobre se tratar de uma questão de saúde pública (indubitavelmente importante), ofuscando a questão da individualidade e da autonomia das mulheres como valor de cidadania (MIGUEL; BIROLI; MARIANO, 2016, p. 127-128). O corpo da mulher ainda é mais facilmente assimilável - ainda que nos setores progressistas - como algo público e tutelável como tal em interesses, e não individualizável e autônomo de modo a ter seu pertencimento como identidade pessoal e única.

No Congresso Nacional, uma frente suprapartidária ${ }^{[5]}$ contra o aborto reuniu, em 2014, 167 deputados (quase um terço da casa, que conta com 513 representantes) e 13

\footnotetext{
${ }^{5}$ O padrão de atuação partidária relacionado ao aborto é variável, não obstante haja recentemente concentração de políticos ligados a igrejas evangélicas neopentecostais nas siglas PR (Partido da República), PSC (Partido Social Cristão) e PRB (Partido Republicano Brasileiro) que unanimemente reúnem manifestações contrárias ao aborto (16 ao todo). O PV (Partido Verde) tem 14 discursos, em regra contra, e destes, 13 do parlamentar Roberto Lucena (contra). No PT (Partido dos Trabalhadores) convivem defensores e adversários, manifestando-se sobre o tema $22,1 \%$ do total dos pronunciamentos da pesquisa referenciada (contra e a favor); PFL/DEM (Partido da Frente Liberal/Democratas) soma 11,6\% do total dos discursos (contra majoritariamente, exceto pelo Dr. Pinotti) e siglas como PP, PPB e PPR, que reúne figuras de sustentação do período da ditadura militar em 10,2\% dos discursos. Em referência aos parlamentares em si, quem mais se manifestou no período (1991-2014) foi Luiz Bassuma (ex-PT, exPV, ex-PMDB, ex-PEN, ex-PROS, atual Avante/PTdoB), líder espírita e um dos autores do "Estatuto do Nascituro", com 65 falas contra o aborto; Severino Cavalcanti (ex-UDN, ex-Arena, ex-PDS, ex-PDC, ex-PL, ex-PPR, ex-PFL,
} 
senadores (dos 81 que compõem o Senado Federal). A luta contra o aborto foi a plataforma de inúmeros candidatos às eleições legislativas recentes, tanto para a Câmara dos Deputados quanto para as assembleias legislativas estaduais. No Horário de Propaganda Eleitoral Gratuita em agosto e setembro de 2014, a "defesa da vida" foi um dos bordões mais recorrentes, ao lado de sua parceira permanente, a "defesa da família". Se muitos candidatos às eleições proporcionais identificavam nas bandeiras da direita religiosa a melhor maneira de sensibilizar o eleitorado, nas eleições majoritárias os candidatos se viram constrangidos a afirmar publicamente sua oposição ao direito de escolha das mulheres. Se não o fizessem, seriam vetados pelos líderes religiosos e sofreriam campanha negativa nas igrejas. (MIGUEL; BIROLI; MARIANO, 2016, p.128)

Mesmo em 2014 com o noticiamento de mortes de mulheres ocorridas em clínicas clandestinas, as ações estatais não foram no sentido de revisar a legislação, mas, a contrário senso, no de aumentar a repressão e a resposta penal contra essas mesmas clínicas e expiar a culpabilização nas pessoas próximas e que estavam cientes de que as mulheres vitimadas utilizariam dos serviços abortivos das referidas clínicas (depois de mortas, são vítimas, mas se não morrem, são autoras do fato típico e sujeitas a tutela penal e liberdade restringida) (LUNA, 2017, p. 1159-1181).

Entre os anos de 1991 a 2014 houve na Câmara 915 pronunciamentos relacionados ao aborto (vide nota de rodapé 3 e 5 deste trabalho) onde constatou-se os posicionamentos de tais discursos, e, inobstante a progressão incontínua das ocorrências, fez-se perceptível a tendência de ampliação dos discursos contrários ao direito. O maior percentual de discursos favoráveis à ampliação do direito ao aborto ocorreu em 1991 (39,4\% - 13 em 33 discursos), percentual que nunca mais ultrapassou 30\%, implicando a zero discursos em 2011, 5 em 2012 (9\%) e zero em 2013 e 2014, revelando a intensificação dos constrangimentos (MIGUEL; BIROLI; MARIANO, 2016, p. 139).

Não se fala nem se falou sobre aborto, porque em regra somente um lado se manifesta, ainda que tenha sido a pauta orientadora de eleições e debates legislativos. Porque falar sobre aborto é compreender do que se trata o fenômeno através da perspectiva de um Estado Democrático de Direito, com espaço para o debate e argumentos, ainda que cientes das incidências fatoriais sobre sua definição, compreender as consequências do tratamento penal sobre o aborto e, se for o caso, como neste trabalho se entende, repensar o modo que tratamos juridicamente sua tutela.

\subsection{MAS O QUE É, AFINAL, ABORTO?}

Aborto não é propriamente uma palavra jurídica, não obstante seu uso terminológico no Direito Penal. Tecnicamente, seria o resultado do abortamento, sendo este o ato em si de interrupção - natural ou não - da gestação antes do desenvolvimento embrionário e/ou fetal completo, mas seu uso corriqueiro e na legislação passou a adotar o significado pela corruptela, que veio a ser aceito como o próprio ato, mesmo pela utilização legal do termo (PRADO, 1985, p. 10). O termo alcança várias áreas, desde a moral à medicina, e é usado desta maneira por elas, tendo indubitavelmente seu conceito de relevância moral confundido com a questão jurídica.

O período gestacional humano dura em média 38-40 semanas, contados a partir da última ovulação da mulher até o parto. Os biólogos empregam termos distintos para distinguir as

ex-PPB, atual PP) com 40 falas contra os direito das mulheres; a favor José Genoíno (PT), em sétimo lugar na quantidade de manifestações totais, com 25, seguido por Marta Suplicy (quando no PT, hoje PMDB) com 19 discursos. (MIGUEL, BIROLI, MARIANO, 2016, p. 137-138)

Revista de Direito Brasileira | São Paulo, SP | v. 20 | n. 8 | p. 378-407 |Mai./Ago. 2018 
etapas da vida humana pré-natal (zigoto, pré-embrião, embrião e feto ${ }^{6}$ ) (DWORKIN, 2003, p.4); para os efeitos dessa pesquisa, mesmo pela vinculação legal sobre aborto que não distingue os momentos e etapas gestacionais, não será feita a distinção destes momentos a priori, e será usado o termo "feto" como regra geral, implicando desde as fases iniciais de desenvolvimento.

No Código Penal brasileiro (artigos 124 a 128) a conduta típica consiste em provocar (dar causa a, originar, promover, ocasionar) aborto. O Código não define o que se entende por aborto, nem estabelece os marcos temporais para sua ocorrência dolosa, portanto é considerado como elemento normativo extrajurídico do tipo, em que sua correta definição exige um juízo de valor empírico-cultural, que, de acordo com Luiz Regis Prado, é feito sobretudo pelas ciências médicas e biológicas. Ainda, o autor afirma que o aborto consiste na "morte dolosa do feto dentro do útero" ou "na violenta expulsão do feto do ventre materno, da qual resulte a morte". Entende-se também suficiente para a configuração do aborto a interrupção da gravidez a qualquer tempo antes do parto - incluindo-se, portanto, períodos gestacionais posteriores a $12^{\mathrm{a}} \mathrm{semana} / 1^{\circ}$ trimestre gestacional. Ainda assim, tais fenômenos, isoladamente considerados, não caracterizam com exatidão o aborto (PRADO, 2005, p. 108).

Conforme se esclarece, a mera interrupção da gestação, por si só, não implica o aborto, uma vez que a gravidez pode ser interrompida com a expulsão do feto e a criança sobreviver, a depender do período gestacional da ocorrência. Em regra, o período de abortamentos naturais ocorre até a $22^{\mathrm{a}}-24^{\mathrm{a}}$ semana gestacional, com pico de incidências até a $12^{\mathrm{a}}-14^{\mathrm{a}}$ semana ${ }^{7}$, sendo a partir da $28^{\mathrm{a}}$ semana configurada a viabilidade fetal, e a partir deste período até por volta da $37^{\mathrm{a}}$ semana gestacional, dá-se a ocorrência dos partos prematuros. Também a expulsão não deve ser considerada como único pressuposto cabível para configuração do aborto, uma vez que seja possível processos de autólise e litopédio (este quando o embrião se calcifica, permanecendo no útero como um corpo anexo; e aquele quando o organismo materno reabsorve o embrião). Ambos nas primeiras semanas de existência.

De modo genérico, o aborto acontece quando o nascituro intra uterum tem sua expectativa de vida frustrada, sendo expulso ou não. De modo específico para os interesses jurídicos, tem se o aborto provocado. Este é fruto da intenção da mãe ou de terceiros, que atuam de modo a interromper o curso da gravidez com o feto em desenvolvimento. E é sobre essa definição que se trabalha nesta pesquisa.

\subsubsection{Aborto na Legislação Brasileira}

O predomínio inicial em relação a tutelas jurídicas sobre o aborto era de total indiferença, sendo considerado, nos primórdios, o feto como parte integrante do organismo materno, e consequentemente sendo critério dela a decisão de prosseguir ou não com a gestação, sendo que utilizar substâncias abortivas era vedado pelo perigo em relação a saúde materna (PRADO, 2013, p. 128-129).

No Direito Romano, inicialmente, não se sancionava a morte dada ao feto, sendo este parte do corpo da gestante, e portanto a ela cabível livre disposição (partus antequam edatur mulieris pars est vel viscerum). A partir do imperador Septimus Severus (193-211 d. C) o aborto passou a ser considerado como lesão ao direito de paternidade, justificado pela frustração das

\footnotetext{
${ }^{6}$ A etapa de zigoto e pré-embrião compreendem a fase germinal, na primeira e segunda semanas, constante em rápida divisão celular de maior complexidade, viagem ao longo da trompa uterina e fixação na parede do útero; a fase embrionária, momento que se tem o embrião, vai em média da segunda à oitava semanas, em que ocorrem o desenvolvimento dos órgão e principais sistemas corporais (respiratório, digestivo e nervoso). Esta é a fase que o embrião se encontra mais vulnerável a influências do ambiente pré-natal e os embriões com defeitos graves originam abortos espontâneos; a fase fetal é estimada da oitava semana até ao nascimento, em que ocorre a maturação do feto até o parto.

${ }^{7}$ A gravidez é uma experiência cheia de ditados populares, conhecimentos comuns e bastante superstição. Vem dessa constatação o conselho dos antigos de não espalhar a notícia da gravidez até o terceiro mês, para a criança "vingar".
}

Revista de Direito Brasileira | São Paulo, SP | v. 20 | n. 8 | p. 378-407 |Mai./Ago. 2018 
expectativas paternas quanto à descendência, cuja penalidade era a mesma do envenenamento doloso. Em sendo auto aborto, a punição era o desterro para a mulher; em sendo praticada por terceiros, além do desterro, imputável a condenação de trabalhos forçados nas minas (damnatio in metallum) aos mais pobres (humiliores) e o rebaixamento de estratificação social bem como confisco de bens e propriedades (relegatio e confiscatio) aos mais abastados, em regra senadores romanos, magnatas e proprietários de terras (honestiores) (PRADO, 2013, p. 129) ${ }^{8}$.

Não obstante a referência autorizada, forçoso que seja dito que à mulher historicamente pouco oficialmente se possuía em sua condição de sujeito e seu corpo em pertencimento de si considerada, sendo uma propriedade da ordem da reprodução e domesticidade (do grego, zoé e oikos), em formatação patriarcal, como se aborda com maiores detalhes no Capítulo 2 desta pesquisa. Assim, a releitura histórica feminista deve vincular/filtrar criticamente tais dados mais tradicionais, bem como as implicações jurídicas de um reflexo social marcado por um Estado formatado de modo muito diverso do que atualmente se compreende como tal, estando estão numa perspectiva de tratamento a partir do Direito Privado, que era como as relações humanas estavam geridas.

Já em terrae brasilis, de acordo com Cezar Roberto Bitencourt (2007, p. 126-150), ao tratar sobre aborto em seu Tratado de Direito Penal (vol. 2), relata que o Código Criminal do Império (1830) não criminalizava o auto aborto (modalidade praticada pela gestante), todavia previa punição na realização por terceiro, com ou sem consentimento da gestante. Havia ainda previsão de punição pelo fornecimento de meios abortivos, mesmo que o aborto não ocorresse. A pena era agravada se o terceiro que praticasse o abortamento exercesse medicina ou afins (BITENCOURT, 2007, p. 126-127). Manifesta ainda que o Código Penal de 1890 distinguia o crime de aborto caso houvesse ou não a expulsão do feto, sendo agravado se ocorresse a morte da gestante; neste Código já se apresenta a versão de punibilidade da gestante que realiza o auto aborto. Porém "se o crime tivesse a finalidade de ocultar desonra própria a pena era consideravelmente atenuada" (BITENCOURT, p. 127). "Ocultar desonra própria" significa deixar de ser virgem - presunção daquela que engravida - fora do matrimônio; a vergonha de tal é tamanha que apta a diminuir pena criminal pela compreensão social da situação da mulher. O teor de moralidade religiosa arraigada na assertiva e na dominação no corpo da mulher controlado pelas estruturas de poder vigentes através do Estado fica evidente.

No Brasil de 2018 o aborto é tutelado pelo Código Penal de 1940, entre os artigos 124 a 128, no capítulo de crimes contra a vida 9 .

\footnotetext{
${ }^{8}$ Importante atentar-se a duas questões que trata-se no feminismo interseccional, e que desde muito, já são delineadas na antiguidade romana: a questão de gênero, uma vez que apenas os interesses do homem e seus herdeiros passaram a ser tutelados, justificando assim a tutela daquilo que se entendia como Estado (uma formatação muito incipiente daquilo que hoje compreende-se como tal), mesmo porquê mulheres estavam invisibilizadas no período, como será aprofundado no Capítulo 2 desta obra; bem como a perspectiva de classe: aos das camadas inferiores, sem posses para negociação, punia-se através da força de trabalho, usando-se os corpos então como meio de castigo; aos abastados, punição de rebaixamento social nas castas e de confisco dos bens.

${ }^{9} \mathrm{Na}$ integralidade da legislação, os artigos do Código Penal:
}

Aborto provocado pela gestante ou com seu consentimento

Art. 124 - Provocar aborto em si mesma ou consentir que outrem lho provoque:

Pena - detenção, de um a três anos.

Aborto provocado por terceiro

Art. 125 - Provocar aborto, sem o consentimento da gestante:

Pena - reclusão, de três a dez anos.

Art. 126 - Provocar aborto com o consentimento da gestante

Pena - reclusão, de um a quatro anos.

Parágrafo único. Aplica-se a pena do artigo anterior, se a gestante não é maior de quatorze anos, ou é alienada ou débil mental, ou se o consentimento é obtido mediante fraude, grave ameaça ou violência 
O bem jurídico tutelado é a vida do ser humano em formação, embora, rigorosamente falando, não se trate de crime contra a pessoa. O produto da concepção - feto ou embrião - não é pessoa, embora tampouco seja mera esperança de vida ou simples parte do organismo materno [...] Comparativamente ao crime de homicídio, apresentam-se duas particularidades: uma em relação ao objeto da proteção legal e outra em relação ao estágio da vida que se protege; relativamente ao objeto, não é a pessoa humana que se protege, mas a sua formação embrionária; em relação ao aspecto temporal, somente a vida intrauterina, ou seja, desde a concepção $o^{10}$ até momentos antes do início do parto. (BITENCOURT, 2018, p. 185) [grifo em itálico do autor; grifo em negrito nosso]

Noutra demarcação temporal quanto ao início da tutela passível de criminalização, segue Luiz Regis Prado, na oportunidade também explicando o bem jurídico tutelado:

O bem jurídico tutelado pelos artigos 124, 125 e 126 do Código Penal é a vida do ser humano dependente, em formação - embrião ou feto. Protege-se a vida intrauterina para que possa o ser humano desenvolver-se normalmente e nascer. O objeto material ou da conduta é o embrião ou o feto humanos vivos presentes no útero da mulher. $\dot{E} d e$ notar que o embrião e o feto não são considerados pessoa, tampouco são titulares de direitos, mas não são coisa, ou algo intermédio, mas deve ser-lhes reconhecido uma condição própria e independente. É a partir da nidação que deve se iniciar a proteção jurídica da vida humana. (PRADO, 2013, p. 133) [grifo nosso]

Não há qualquer menção ao aborto na Constituição da República. Assim, em regra, a prática é vedada criminalmente, passível de pena para a gestante que põe fim dolosamente à gestação, bem como a terceiros que possam auxiliá-la ou obrigá-la a tal. A autoria recai somente na mulher, uma vez que é no corpo dela que se aloca o fato delitivo; o direito penal e sua estrutura de responsabilização se volta contra ela no auto aborto ou sob seu consentimento (art. 124 do Código Penal), e paralelamente o peso moral da decisão e do julgamento social, estruturados na criminalização secundária.

Excepcionalmente, a legislação prevê duas excludentes de ilicitude (conforme doutrina majoritária na interpretação do tema, muito embora a redação da lei diga "não se pune", implicando no que seria excludente de punibilidade), qual seja, o aborto necessário (advindo da necessidade de salvar a vida da gestante) e o aborto humanitário (em razão de estupro). Mais recentemente [2012] o Supremo Tribunal Federal decidiu, na ADPF 54, que é causa excludente de tipicidade o chamado aborto eugênico, que autoriza o procedimento para os casos de anencefalia $^{11}$. Tal declarou, por maioria e nos termos do voto do relator, inconstitucional a

Art. 127 - As penas cominadas nos dois artigos anteriores são aumentadas de um terço, se, em consequência do aborto ou dos meios empregados para provocá-lo, a gestante sofre lesão corporal de natureza grave; e são duplicadas, se, por qualquer dessas causas, lhe sobrevém a morte.

Art. 128 - Não se pune o aborto praticado por médico:

Aborto necessário

I - se não há outro meio de salvar a vida da gestante;

Aborto no caso de gravidez resultante de estupro

II - se a gravidez resulta de estupro e o aborto é precedido de consentimento da gestante ou, quando incapaz, de seu representante legal.

${ }^{10} \mathrm{O}$ entendimento sobre o início da tutela temporal ser a partir da concepção não é unânime, tendo inclusive, tolerância doutrinária moderna referendando o início temporal como a partir da nidação (momento em que o óvulo se fixa na parede uterina), uma vez que, ao considerar-se a partir da concepção, métodos contraceptivos como o DIU de cobre, bem como a chamada "pílula do dia seguinte" seriam abortivos para os fins do Código Penal.

11 Ainda antes da decisão do Supremo a respeito, Bitencourt (2007, p. 140-150) já sustentava que considerar a hipótese do aborto anencefálico como fato atípico seria medida de respeito a dignidade humana da gestante, inexistindo fundamento para censura social. Argumentava então que o enfrentamento começava a partir do exame da (in)adequação da denominação aborto, "na medida em que se trata de feto sem vida, ou, na linguagem médica

Revista de Direito Brasileira | São Paulo, SP | v. 20 | n. 8 | p. 378-407 |Mai./Ago. 2018 
interpretação de que o feto anencéfalo é conduta tipificada nos arts. 124, 126 e 128, incs. I e II do Código Penal, solucionando a polêmica sobre o direto da mulher em voluntariamente interromper a gestação em se tratando desta comprovadamente de feto portador de anencefalia (PIRES, 2016, p. 362).

A Arguição de Descumprimento de Preceito Fundamental 54 (ADPF 54) foi proposta em 2004, tendo autorização para a interrupção das gestações vigorado intermediariamente através de liminar por quatro meses e revogada em 20 de outubro do mesmo ano. A decisão quanto ao mérito apenas ocorreu em 2012. Até então, as mulheres que pretendessem pela interrupção tiveram que judicializar a questão. Muitas levaram, diante da negativa pelo Judiciário, a gestação até o parto amadurecido, para de lá saírem sem seus filhos.

A anencefalia é um distúrbio de fechamento do tubo neural diagnosticável nas primeiras semanas de gestação. Por diversas razões, o tubo neural do feto não se fecha, deixando o cérebro exposto. O líquido amniótico gradativamente dissolve a massa encefálica, impedindo o desenvolvimento dos hemisférios cerebrais. Não há tratamento, cura ou qualquer possibilidade de sobrevida de um feto com anencefalia. Em mais da metade dos casos, os fetos não resistem à gestação, e os poucos que alcançam o momento do parto sobrevivem minutos ou horas fora do útero. O Brasil é o quarto país do mundo em número de partos de fetos com anencefalia. [...]. O argumento jurídico e ético da ação apresentada à Suprema Corte baseou-se na certeza científica da impossibilidade da vida extrauterina do feto. A anencefalia exige uma reconfiguração dos termos descritivos tradicionalmente utilizados no debate sobre o aborto em países com forte tradição moral cristã. (DINIZ; VÉLEZ, 2008, p. 648)

A defesa da causa realizada pelo então advogado e professor Luis Roberto Barroso foi sustentada no sentido de que a inviabilidade fetal extrauterina era uma certeza, não sendo possível argumentar sobre interesses fetais sob tutela, posto que inexistentes; desta forma, a discussão circunscrevia-se aos direitos constitucionais das gestantes, pontuando em relação ao mérito que a criminalização da antecipação terapêutica de feto anencefálico vulnera o preceito da dignidade da pessoa humana (art. $1^{\circ}$, IV CR), o princípio geral da liberdade derivado do princípio da legalidade (art. 5\% inc. II CR) bem como ao direito à saúde (arts. $6^{\circ}$ e 196 CR) (PIRES, 2016. p. 363). Assim, o corpus decisório dos ministros não se ateve à discussão sobre o início da vida e sim à sua potencialidade, cientes da inviabilidade extrauterina nestes casos. A decisão não tratou de trazer uma nova excludente de ilicitude a juntar-se com as demais supracitadas, sob pena do

moderna, trata-se de um feto com morte cerebral. Examinando-se nosso Código Penal de 1940, constata-se que o legislador de então, ao criminalizar o aborto, não foi radical, pois admitiu como lícito, ainda que excepcionalmente, $o$ aborto necessário e o aborto sentimental (art. 128). Isso permite concluir que, se, na época, houvesse o arsenal de conhecimento e tecnologia de hoje, provavelmente também teria admitido o denominado aborto anencefálico, diante da absoluta certeza da inexistência de vida, como ocorre na atualidade" (BITENCOURT, 2007, p. 141). Continua, manifestando que "O entendimento do legislador brasileiro, não há dúvida alguma, seguindo a evolução médicocientifica, reconhece que 'a morte cerebral' põe termo à vida humana. Ora, se a 'morte cerebral' significa a morte, ou, se preferirem, ausência de vida humana, a ponto de autorizar o "esquartejamento médico" para fins científicohumanitários, o que se poderá dizer de um feto que, comprovado pelos médicos, nem cérebro tem? Portanto, ainterrupção de gravidez em decorrência de anencefalia não satisfaz aqueles elementos, que destacamos anteriormente, de que 'o crime de aborto pressupõe gravidez em curso e é indispensável que o feto esteja vivo', e ainda que 'a morte do feto seja resultado direto das manobras abortivas'. Com efeito, na hipótese de anencefalia, embora a gravidez esteja em curso, o feto não está vivo, e sua morte não decorre de manobras abortivas. Diante dessa constatação, na nossa ótica, essa interrupção de gravidez revela-se absolutamente atípica e, portanto, sequer pode ser tachada como aborto, criminoso ou não." (BITENCOURT, 2007, p. 145) [grifos do autor]. O posicionamento do autor é mais "cru”, e não pormenoriza questões como potencialidade ou expectativa de vida viável, como fez-se na ADPF 54, mas certamente possui sua contribuição no sentido de atipicidade da conduta, conforme destacou-se nos trechos citados, e tem se mantido em edições mais recentes de sua obra (BITENCOURT, 2018). 
Judiciário imiscuir-se no Poder Legislativo em sua função típica de fazedor de leis; neste caso em específico não foi criada uma nova condição de excepcionalidade nem discutiu-se a possibilidade de ampla descriminalização, haja vista que não analisou-se a constitucionalidade do tipo penal do aborto em si, mas o reconhecimento da impossibilidade de concretização da vida em gestações como tais, declarando-se a atipicidade da conduta penal das hipóteses de aborto arroladas no Código Penal para os casos de anencefalia - assim, as mulheres que compreenderem por não levar a gestação adiante a partir da constatação médica, poderão, se assim entenderem adequado, realizar o procedimento de aborto (“antecipação terapêutica”) sem que seja uma conduta criminosa.

Ao analisar a descriminalização judicial da chamada "antecipação terapêutica do parto", Teresinha Pires manifesta que a ADPF 54 proporcionou significativo progresso no que se refere à concretização de liberdades individuais no cenário da jurisdição constitucional brasileira. Reporta, ainda que os direitos reprodutivos da mulher passam por processo de aperfeiçoamento, sendo que as Cortes Constitucionais, em geral, vêm procurando elucidar o seu âmbito de proteção da forma mais consentânea possível com o estágio atual da ciência médica e com as novas demandas femininas. A decisão da Corte brasileira, no caso, seguiu, nos limites do objeto da arguição, os parâmetros internacionais de crescimento do amparo jurídico às escolhas da mulher em relação ao controle do seu próprio corpo e à sua autonomia moral. É um precedente que, em sequência ao julgamento da ADIn 3510, aperfeiçoou, em linhas gerais, os critérios de análise constitucional para o enfrentamento do problema do aborto, constituindo indubitável referência analítica em relação a eventuais ações judiciais futuras que versem sobre a matéria (PIRES, 2016, p. 368).

Não obstante as exceções apontadas, o aborto ainda é um fato típico tutelado pelo Direito Penal, e mesmo os autores de Direito Penal utilizados e amplamente conhecidos desde a graduação (ou seja, não são sujeitos pontuais e excepcionais, são dogmática e cientificamente reconhecidos e referendados) - Bitencourt e Regis Prado - não enfrentam as discussões sobre a ampliação descriminalizadora nas primeiras semanas gestacionais, como ocorre legalmente em grande parte dos países europeus. Justiça seja feita, menciona-se de modo sintético, literalmente, na expressão "calha a síntese" uma exposição empobrecida da pauta descriminalizadora/legalizadora ${ }^{12}$ (in PRADO, 2013, p. 131), bem como em edição após o Habeas Corpus n. 124.306/RJ, em que Luiz Regis Prado se posiciona, referindo que merece destaque o voto do Ministro Barroso (estudado adiante, no item 3.1.2 deste) porém que

Odireito à vida, constitucionalmente assegurado (art. $5^{\circ}$, caput, $\mathrm{CF}$ ), é inviolável, e todos, sem distinção, são seus titulares. Logo, é evidente que o conceito de vida, para que possa ser compreendido em sua plenitude, abarca não somente a vida humana independente, mas também a vida humana dependente (intrauterina).(PRADO, 2018, p. 90).

Essa inviolabilidade indistinta do direito à vida é falaciosa, ainda que de força retórica, porque existem hipóteses amparadas por lei de relativização da vida como conceito amplo, exemplificativamente, como tratou-se e ainda se abordará neste texto. Desconsidera, na generalização posta, qualquer possibilidade de autonomia e interesses da mulher em sua amplitude como indivíduo, bem como se vincula com uma interpretação eivada de moralidade (ainda que não consciente/declarada) a referir-se à punição da sexualidade da mulher pelo Direito

\footnotetext{
${ }^{12} \mathrm{Na}$ literalidade: "Na atualidade, o aborto provocado é incriminado em grande parte das legislações. Não obstante, disseminam-se as vozes que se elevam contra essa tipificação. Embora vários os argumentos expendidos, calha a síntese: a) o feto é parte da mulher e esta pode dispor do produto da concepção; b) a vida do feto não é um bem jurídico individual, mas um interesse da sociedade a ser protegido em alguns casos; c) a pena não logra evitar as práticas abortivas; d) o aborto é uma lei de exceção endereçada às classes sociais mais pobres; e) é necessário proteger a vida e a saúde das numerosas mulheres que recorrem ao aborto clandestino." (PRADO, 2013, p. 131)
}

Revista de Direito Brasileira | São Paulo, SP | v. 20 | n. 8 | p. 378-407 |Mai./Ago. 2018 
Penal, com uma leitura conservadora e pouco crítica do tipo penal e da função exercida por esse ramo do Direito como fomentador da dominação e dos interesses dos estratos dominantes.

E este fato - a tutela criminal e a forma de tratamento na doutrina pátria - é simbolicamente demonstrativo do comprometimento legal das políticas públicas em relação ao tema. Estar o aborto alocado na legislação brasileira unicamente no Código Penal é uma manifestação muito clara de uma escolha de política pública - criminal - pontual do legislador de 1940 (e sua manutenção por ali, igualmente, uma manifestação muito clara do Legislativo que se perpetua).

A tutela que o legislador optou a dar para o tema foi criminal, a resposta mais pesada que o Estado pode dar, e nesse caso especificamente num "público alvo" que foge àquele tradicionalmente vinculado ao direito penal: em tese alcança-se todas as classes sociais e raças (evidentemente agrava-se quanto à mulher pobre e negra, por fatores que serão discutidos adiante) mas o enfoque é única e exclusivamente nas mulheres biologicamente identificadas, em capacidade reprodutiva, claramente criminalizando atos vinculados a elas pela natureza do tipo.

Sobre o uso do Direito Penal como meio coercitivo, Zaffaroni manifesta tratar-se de uma armadilha neutralizante e retardatária, pois o poder punitivo opera sempre seletivamente, se repartindo conforme a vulnerabilidade e esta, por sua vez, respondendo a estereótipos. Os estereótipos se constroem atribuindo negatividade a imagens carregadas de preconceitos que contribuem com a sustentação cultural das discriminações, sendo a seleção criminalizante o último produto de todas as discriminações. A essas condições e características dos sujeitos em situação de prisão obedecem a essa estrutura discriminatória posta, reiterando a classificação de acordo com os preconceitos que determinaram a seleção desses mesmos sujeitos (ZAFFARONI, 2001, p. 66) ${ }^{13}$ ao se observar quem são as mulheres que abortam no Brasil, naquilo que se consegue apurar (posto se tratar de ato criminalizado) e quem são as mulheres que sofrem as consequências jurídicas de tal.

A relação feminina com as questões delitivas resultantes nas implicações de tutela tem uma raiz histórica importante de ser mencionada para a finalidade de compreensão de tal tratamento e de seu modo operante vinculado ao controle da sexualidade e dos seus corpos e do uso do poder político nos indivíduos desenvolvidos através da estruturação social vinculada ao sexo que Foucault (2014 [1984]) chama de biopoder (e que vem a ser fundamental para o desenvolvimento das pesquisas sobre gênero e sexo de Butler). Weigert (2017) explica que entre os séculos XII e XIII o controle político do corpo social da Igreja estava fundido ao Estado e os tribunais eram os tribunais da Inquisição, em que necessariamente a mulher é pensada como um demônio, portanto, estudadas em seus comportamentos delitivos pelas teorias demonológicas, cujos mistérios e segredos, desde a vinculação à imagem da bruxa em cozinhar, ter conhecimento herbal de remédios (vinculados ao paganismo e que implicaram na remoção das mulheres como identificadas com as práticas médicas, hoje nobres), perda sanguínea menstrual, conhecimentos sobre reprodução, et catera, deveriam ser tidos com cautela, posto oferecimento de risco e perigo gerado pela estranheza feminina.

Temia-se o que não se conhece/compreende, logo, deriva-se a necessidade de controle ${ }^{14}$, controle inclusive exercido pela diminuição de suas faculdades mentais (não sem motivos -

\footnotetext{
${ }^{13}$ No original: "En cuanto a la relación del discurso feminista y el discurso del poder punitivo, si bien tiene particularidades, la trampa neutralizante y retardatária no es em lo básico diferente de las que amenazan a los otros discursos antidiscriminatorios. [...] El poder punitivo siempre opera selectivamente: se reparte conforme a la vulnerabilidad y ésta responde a estereotipos. Los estereotipos se construyen em relación com imágenes negativas cargadas com todos los prejuicios que contribuyen al sostenimiento cultural de las discriminaciones.Por carácter transitivo, puede afirmarse que la selección criminalizante es el produto último de todas las discriminaciones.A ello obedecen las características comunes de los prisionizados, que pueden ser classificados según los prejuicios que determinaron su selección.” (ZAFFARONI, 2001, p. 66).

${ }^{14}$ Mary Del Priore (2011, 1. 294 e 313) explica que o controle dos corpos femininos também ocorria no Brasil Colônia, exercido pela Igreja, que via perigo na beleza e sexualidade da mulher, reprimindo a vaidade feminina (que,
}

Revista de Direito Brasileira | São Paulo, SP | v. 20 | n. 8 | p. 378-407 |Mai./Ago. 2018 
referendados pela "ciência" - a desqualificação da mulher pela loucura é ainda cotidiana), vinculados às característica da fala (grito, fofoca, e afins, construídos como valores pejorativos em equivalência ao feminino e posteriormente relacionados à histeria freudiana), que implica que a facilidade de expor também expõe o que não é para ser exposto dentro da ordem política realizada, daí a necessidade de controle e sua diminuição e taxatividade com a "loucura", com o escopo de desqualificação da mulher na condição de sujeito racional ${ }^{15}$.

Implicou-se o controle da mulher pela violência (caça às bruxas) por não estar dentro do padrão comportamental esperado, que se consolida na vinculação a sua sexualidade (é a partir de sua condição de mulher que se relaciona suas transgressões) que equivale a dizer que tal sexualidade implica em seu desvio e nas práticas desviantes, necessariamente equivalendo o delito ao pecado. No Malleus Maleficarum (2016 [1486/7]) as "bruxas" pagam seus crimes todos eles - com suas próprias vidas, num ritual de expiação da alma deste pecado/delito do exercício de controle da sexualidade. O que legitima a punição pela normatização do comportamento feminino porque elas são relacionadas ao demônio, logo, exercem risco ao poder político exercido pela fé, devendo ser oprimidas em suas potencialidades: devendo ser controladas.

Lombroso (1835-1909), já fora do período de Inquisição, herda, por assim dizer, uma sociedade estruturada e está inserido num contexto em que as explicações devem ser referendadas pela ciência, que eram necessárias também a fim de explicar as humanidades. Através da metodologia da empiria traz ao estudo do crime - aqui já como um ente jurídico e não como heresia - e suas variáveis criando o chamado paradigma etiológico (ethos: causas, origens), objetivando descobrir as origens da delinquência (WEIGERT, 2017).

Conjuntamente a seu genro, Guglielmo Ferrero, em La Donna Delinquente: La Prostituta e La Donna Normale (1903), revelam, em leitura atual, a percepção de seu tempo sobre a mulher - que perdura moralizante e moralizada até nossos dias -, diferenciando a "normal" da "prostituta" (já no título, equivalendo esta à condição de delinquência, da conduta desviante) diz que a mulher tem como capital de si o capital sexual, uma vez que a virgindade é valorizada e define as mulheres entre "decentes" e "promíscuas". Estas últimas não souberam capitalizar seu corpo e a elas, cabe a pecha de "mulheres prostitutas" (LOMBROSO; FERRERO, 1903, p. 211-260); a delinquência entre homens é superior à feminina, mesmo porque, justificam, a delinquência da mulher está no corpo (LOMBROSO; FERRERO, 1903, p. IX), o que, numa análise feminista da colocação, evidencia que ao fim e ao cabo a tutela penal proibitiva do aborto vem como punição social à mulher "promíscua" (e em "promíscua" cabe muita significação): pune-se pelo corpo o desvio desse corpo a obrigando a ter uma gestação (e criar a criança como prova) ou utiliza-se o sistema criminal para evidenciar seu caráter "criminoso e ardil" ao tentar ocultar a gravidez. O corpo é sempre a prova do crime de ser mulher.

Zaffaroni ensina que a falha em Lombroso estava nas explicações, uma vez que ele confundiu as causas da criminalização com as causas do delito. Quanto às mulheres, reporta que as poucas presas tinham características virilizadas, mas não por tal seriam anormais: a partir da observação de Lombroso, Zaffaroni percebe que se deduz apenas que o poder punitivo de seu tempo selecionava as mulheres que implicavam no estereótipo das mulheres virilizadas como desviado de seu papel de mulheres submissas e domésticas. Reporta ainda que também não era verdade que a prostituição fosse equivalente à prisão, no que se refere a uma maneira de manter as mulheres subordinadas, escravizadas como mercadoria de um homem que a aluga por período determinado, senão uma situação de servidão que torna desnecessária a intervenção controladora

para os pregadores, visava a sedução dos homens, sendo um veículo de perdição para eles, naturalizado na ideia de que a mulher é velha amiga da serpente) e fustigando o corpo feminino, o relacionando ao pecado e às forças diabólicas da teologia cristã.

15 Disto considerado, compreensível a ordem de tratamento da mulher ainda vigente em sua diminuição de autoridade em local de fala e de ser ouvida e respeitada como tal em seus posicionamentos. 
do poder punitivo sobre ela (ainda que a diferencie da "donna normale"). É a manifestação máxima do patriarcado que o sistema penal reforça, para delegar e salvar o esforço de controle sobre metade da população, como resultado da grande privatização, no sentido de zelar por interesses privados e não públicos, do poder punitivo, anterior em muitos séculos às recentes iniciativas de privatização da segurança (ZAFFARONI, 2001, p. 67-68) ${ }^{16}$.

Ainda assim, o que levou o legislador de 1940 a tratar o aborto como crime são fatores socioculturais compreensíveis pelo relativismo cultural, diante do tempo em que se impôs em vigência tal legislação, tendo trabalhado, para o período, em regime de razoabilidade ao estipular hipóteses de não incidência da punibilidade, ainda que deixando muito claro que a prioridade seria o feto. Porém, a realidade social provocada com tal legislação implica em questões pouco abordadas ou que não ficam claras com a mera leitura legal. O que se questiona é o anacronismo da manutenção em vigência de um instituto normativo que tem sido abolido nas democracias mais desenvolvidas desde a década de 1970. Ainda que considerado os anos de chumbo do período de ditadura militar, o Brasil é declaradamente democrático há trinta anos. Pesquisa divulgada no II Plano Nacional de Políticas Para as Mulheres $\left(2008\right.$, p. 75) ${ }^{17}$ já manifestava o problema pelas bases do tratamento como questão de saúde pública, assim o reconhecendo, ciente de que o Brasil pratica o aborto ilegal, notabilizando que em 2006 foram realizados 2067 abortos legais, previstos no artigo 128 do Código Penal Brasileiro que permite a realização do procedimento nos casos de risco de vida para a mulher e de gravidez resultante de estupro. No mesmo ano, no Sistema Único de Saúde, foram realizadas 222.840 curetagens pós-aborto, das quais 37 resultaram em óbitos maternos.

Há que se dizer que percepção equivalente já havia sido manifestada anteriormente, no documento base intitulado de Contribuição da Secretaria Especial de Políticas para as Mulheres Para as Conferências Estaduais (2004), realizado no I Plano Nacional de Políticas Para as Mulheres em 2004, que manifestava sobre o tema, já transversalmente considerando fatores de raça e socioeconômicos, basicamente que compreende as causas principais de mortalidade materna como hemorragias, hipertensão, infecções puerperais, doenças do aparelho circulatório complicadas pela gestação, parto, puerpério e aborto. Supõe-se que, em $92 \%$ dos casos, estes óbitos poderiam ser evitados. As dificuldades de acesso aos serviços de atendimento ginecológico e obstétrico são maiores para as mulheres negras: são constatadas diferenças relacionadas com número de exames ginecológicos, consultas pré-natal e até mesmo com a proporção de parturientes que receberam ou não anestesia, com nítidas desvantagens para as mulheres negras. $\mathrm{O}$ aborto no Brasil continua sendo um problema de direito individual e de direito social. Mesmo nos casos previstos por lei, as mulheres enfrentam a interferência e a pressão de setores conservadores e têm que recorrer à justiça para fazer valer os seus direitos. Calcula-se que cerca de 1,2 milhão de abortos são feitos por ano no país, causando $9 \%$ das mortes maternas e $25 \%$ das esterilidades ainda respondem pela quinta causa de internações

\footnotetext{
${ }^{16}$ No original em espanhol: "En cuanto a la mujer, era cierto que las pocas presas que había en aquel momento tenían características virilizadas, pero no que las mujeres delincuentes fueran anormales: de su observación, lo que se deduce es sólo que el poder punitivo de su tiempo seleccionava mujeres conforme al estereotipo de la mujer virilizada como desviada de su cometido de hembra sumisa y doméstica. Tampoco era verdad que la prostituición fuera un equivalente de la prisionización: una forma de mantener subordinada a la mujer, esclavizada como mercancía de un hombre que la alquila. Esa situación de servidumbre hace innecesaria la intervención controladora del poder punitivo sobre ella. Es la máxima manifestación del patriarcado que el sistema penal refuerza para delegar y ahorrarse el esfuerzo controlador sobre la mitad de población. Es el resultado de la gran privatización del poder punitivo, anterior en muchos siglos a las iniciativas recientes de privatización de la seguridad." (ZAFFARONI, 2001, p. 67-68)

${ }^{17}$ II Plano Nacional de Políticas para as Mulheres. Brasília: Secretaria Especial de Políticas para as Mulheres, 2008. Disponível em < http://portal.mec.gov.br/dmdocuments/planonacional_politicamulheres.pdf > Acesso em 01 de Maio de 2018.
} 
hospitalares, com 250 mil casos de complicações. Apesar de legalmente previsto, até 2002 apenas 46 serviços 28 em todo o país realizavam esse tipo de atendimento (2004, p. 26-28).

É importante descortinar o que implica na prática tal normatividade restritiva, e a dificuldade que as mulheres que buscam o aborto legal no Brasil enfrentam. Apesar da previsão legal genérica, não há um protocolo sobre como proceder em casos como tais - sobretudo em caso de estupro, uma vez que, quando se trata de risco à vida da mulher e anencefalia, em regra as mulheres nesta posição já estão amparadas por serviços de saúde dadas as especiais naturezas médicas dos casos. Desde 2005 há uma nota de recomendação do Ministério da Saúde, reeditada em 2011 e que ganhou recomendação de lei em 2013, para que, nos casos de estupro não haja a necessidade de haver um boletim de ocorrência - o que quer dizer que a mulher estuprada pode e deve, pela urgência e demais medidas de profilaxia - buscar em primeira mão centros de saúde. Foi o reconhecimento indireto de que o aborto é assunto de saúde pública e não de polícia.

O Ministério da Saúde, até 2016, dizia que em toda a linha do Sistema Único de Saúde (SUS) que ofereça serviços obstétricos e ginecológicos estão autorizados a realizarem o aborto legal, mas há um profundo desconhecimento por parte dos agentes, e estes ainda podem alegar objeção de consciência para não realizar o procedimento.

A objeção de consciência é um dispositivo normativo de códigos profissionais e de políticas públicas que visa proteger a integridade de pessoas envolvidas em uma situação de conflito moral. Em um conflito entre deveres públicos e direitos individuais, esse dispositivo é acionado para proteger a moral privada do indivíduo, como no caso do médico que declara objeção de consciência para não atender uma mulher que deseja abortar legalmente. Em nome de convicções individuais, esse dispositivo protegeria o sentimento de integridade moral do médico, ao autorizá-lo a não participar de um procedimento que acredita ser moralmente errado, embora legal. [...] O médico pode alegar objeção de consciência diante de uma situação concreta de pedido de aborto por uma mulher, desde que não o faça por desconfiança quanto ao estupro, por exemplo, mas estritamente por razões de sua moral privada, como é o caso das crenças religiosas. Não cabe ao médico ou à equipe de saúde o julgamento sobre a narrativa do estupro, e o boletim de ocorrência policial nem sequer é necessário, pois há "presunção de veracidade na palavra da mulher". Ao alegar a objeção de consciência, o médico solicita a recusa em cumprir com seu dever. A mulher é atendida por outro médico, encaminhada a outro serviço ou, em casos extremos, pode ficar sem assistência. As normas técnicas do Ministério da Saúde não reconhecem o direito à objeção de consciência se existir risco de morte, se não houver outro médico ou se a omissão médica causar danos à mulher, mas casos concretos mostram o descumprimento desses critérios normativos. (DINIZ, 2011, p. 982)

Em tese, existem 68 estabelecimentos referenciais que o realizam, cujos nomes não são divulgados sob a alegação de segurança. Entre os anos de 2013 e 2015 estudou-se nacionalmente os serviços de aborto legal no Brasil, por Alberto Pereira Madeiro e Debora Diniz (2016), manifestando que inicialmente, ainda que existentes no Código Penal as excludentes desde a década de 1940, a acesso aos serviços de saúde não foi regulamentado por quase 50 (cinquenta) anos. A nível municipal, em 1989, São Paulo capital implantou o primeiro serviço de atendimento às mulheres vítimas de violência sexual no Hospital Municipal Artur Ribeiro de Saboya ("Hospital do Jabaquara") ${ }^{18}$. Na ocasião, para ter acesso ao serviço havia a necessidade

\footnotetext{
${ }^{18}$ Em notícia de Fevereiro de 2018, reporta-se que os serviços de aborto legal do hospital foram encerrados pela gestão do prefeito João Doria (PSDB): "O serviço de aborto legal do Hospital Municipal Arthur Ribeiro Saboya, conhecido como Hospital Jabaquara, na zona sul de São Paulo, foi desativado pela gestão do prefeito João Doria $(P S D B)$ há pelo menos cinco meses.A secretaria municipal de Saúde alega aposentadoria dos profissionais que atuavam na equipe responsável para justificar o encerramento das atividades, mas há suspeitas de que se trata de Revista de Direito Brasileira | São Paulo, SP | v. 20 | n. 8 | p. 378-407 |Mai./Ago. 2018
} 
de apresentação de Boletim de Ocorrência e laudo pericial do Instituto Médico Legal (IML). Em 1999 a regulamentação alcançou nível nacional, através da norma técnica de Prevenção e Tratamento dos Agravos Resultantes da Violência Sexual contra as Mulheres e Adolescentes, que foi atualizada nos anos de 2005 e 2011 a fim de isentar a necessidade de apresentar boletim de ocorrência ou laudo do IML, sendo a partir de então necessário tão somente a manifestação escrita da mulher, oficialmente declarado pelo Ministério da Saúde que haviam 60 (sessenta) serviços disponíveis (MADEIRO; DINIZ, 2016, p. 564).

Entretanto, constatou-se significativa ignorância por parte dos médicos em relação ao procedimento, caracterizada por dúvidas e estigmatizações, que alega objeção de consciência para impossibilitar o exercício do direito das mulheres que precisassem fazer uso de tal. Ainda, reporta que no ano de 2005 foram realizadas duas pesquisas quanto ao atendimento nos serviços públicos a mulheres vítimas de violência sexual, em que a primeira delas avaliou 56 hospitais listados como serviços especializados para a interrupção da gravidez prevista em lei. Os dados mostraram que somente 37 deles estavam capacitados para o aborto legal, que 5 nunca tinham realizado esse procedimento e que, em 6 estados, não havia serviço estruturado. Além disso, 70\% dos atendimentos ocorreram na região Sudeste, cujos serviços receberam encaminhamentos de todas as regiões do país14. O segundo estudo, que entrevistou gestores e profissionais de 1.395 estabelecimentos de saúde que prestavam atendimento às mulheres vítimas da violência sexual, mostrou que apenas $12 \%$ dos serviços haviam realizado pelo menos um aborto, $53 \%$ ofertavam anticoncepção de emergência e $45 \%$ ofereciam profilaxia contra HIV. [A partir de 2012, nos casos de anencefalia, também abarcados] O Conselho Federal de Medicina, por meio da Resolução n. 1.989, de 10 de maio de 2012, estabeleceu os critérios para a antecipação terapêutica do parto de feto anencéfalo (MADEIRO; DINIZ, 2016, p. 564).

Quanto ao perfil dos serviços prestados, foi apurado 68 serviços, dos quais 37 efetivamente funcionavam e realizavam interrupção de gravidez por estupro, 27 por risco de morte e 30 por anencefalia. Dois destes 37 hospitais, em gestações acima de 14 semanas, encaminhavam o caso para outro serviço. No que se refere aos serviços inativos, 28 deixaram de prestar o serviço, e 4 nunca o realizaram de fato. Quanto aos $37 \mathrm{em}$ atividade, 29 foram implementados até 2005, e 8 estruturados após a data. Geograficamente, no Brasil, são distribuídos em 20 (vinte) Estados (5 na região Norte, 11 no Nordeste, 3 no Centro-Oeste, 6 no Sul e 12 no Sudeste); mas em 7 Estados não há serviço ativo (1 na região Sul, 1 no Centro-Oeste, 2 no Nordeste e 3 no Norte). Apenas em 6 Estados há mais de 1 serviço, e em 4 deles existem serviços localizados fora das capitais (8 cidades). Das 37 instituições que efetivamente funcionam e realizam o procedimento, informam possuir equipe especializada (médico, enfermeiro, psicólogo e assistente social) no atendimento às mulheres vítimas de violência sexual; não obstante, em 35 não havia equipe específica, e o atendimento é realizado por plantonistas (MADEIRO; DINIZ, 2016, p. 566).

Quanto as mulheres atendidas e de seus abortos realizados de forma legal, analisaram-se 1.283 prontuários em 5 serviços de cada região do país, sendo que em apenas um deles realizouse $80 \%$ dos procedimentos. A faixa etária concentrou-se entre os 15 aos 29 anos (62\%), solteiras (71\%), escolarizadas até o ensino médio (37\%) e católicas (43\%), destacando-se que 38\% delas ainda eram crianças e adolescentes, e 05 tinham menos de 10 anos. O motivo principal foi

uma decisão política, e que coloca em risco a vida das mulheres. 'Uma mulher com melhor situação financeira consegue um aborto.O problema é que esse atendimento era voltado para as pessoas que não têm condições de pagar um aborto seguro', afirmou a conselheira de Saúde Ana Rosa Costa à repórter Michelle Gomes, para o Seu Jornal, da TVT.Inaugurado em 1989, durante a gestão da prefeita Luiza Erundina, o serviço do aborto legal no Hospital Jabaquara foi o primeiro no Brasil e na América Latina, e rapidamente se tornou referência.[...]" Disponível em < http://justificando.cartacapital.com.br/2018/02/01/gestao-doria-desativa-servico-de-aborto-legal-dohospital-jabaquara/ > . Acesso em 10 de Maio de 2018. 
estupro (94\%). Idade gestacional predominante entre 9 e 14 semanas (41\%), acima de 20 semanas, considerou-se antecipação do parto por anencefalia (5\%); utilizou-se como método para o aborto aspiração manual intrauterina (45\%) e do misoprostol (32\%) (MADEIRO; DINIZ, 2016, p. 566). A pesquisa conclui ${ }^{19}$ que apesar de previsto em lei, na prática o aborto legal é ínfimo, tanto por ignorância de seu procedimento como pela substancial ausência e ignorância das e etapas e de instituições que o realizem.

Ainda em pesquisas relacionadas ao aborto no Brasil, em 2010 e em 2016 Debora Diniz (et al, 2017) realizou a PNA - Pesquisa Nacional de Aborto $^{20}$, para tentar revelar ou estimar com maior precisão a quantidade de abortos não amparados por excludentes que ocorrem no Brasil. Utilizando-se de técnica de urna a fim de mapear os abortos realizados no país de modo a revelar esses números que ainda são aproximados, dada a condição de crime (além da questão moral) que envolve o tópico. O público, tanto em 2010 quanto em 2016, foram mulheres alfabetizadas entre 18 e 39 anos nas áreas urbanas dos municípios, o que exclui, ainda que possível de projeção, índices das mulheres de áreas rurais. E o que se revelou foi o perfil predominante da mulher que aborta no Brasil: ela é religiosa, está no auge de seu período fértil, ainda que amadurecida,e já foi mãe anteriormente. Foram entrevistadas 2.002 mulheres na pesquisa de 2016, e destas 13\% (251) já fizeram ao menos um aborto, proporção semelhante à PNA 2010, que ficou em 15\%.

Os pesquisadores explicam que, como a pergunta é sobre realizar aborto ao longo da vida, as taxas tendem a ser maiores entre mulheres mais velhas. Na faixa etária de 35 a 39 anos, aproximadamente $18 \%$ das mulheres já abortou. Entre as de 38 e 39 anos a taxa sobe a quase $19 \%$. A predição por regressão linear das taxas de aborto pelas idades é de que a taxa a 40 anos é de cerca de $19 \%$. Dois terços $(67 \%, 18)$ das mulheres que confirmaram ter abortado em 2015 (27) foram internadas para finalizar o aborto. Essa proporção difere da presumida em diferentes cenários usados para estimar o número anual de abortos por métodos indiretos, baseada no número oficial de mulheres internadas por complicações do aborto na rede pública, com aplicação de fatores de correção para se estimar o número de abortos induzidos. Essas estimativas utilizam cenários em que $16 \%, 20 \%$ ou $28 \%$ das mulheres que abortaram necessitaram de hospitalização por complicações, multiplicando por 6,5 ou 3,5 o número de internações por aborto. Os resultados das PNA 2010 e 2016 sugerem que esse fator deve ser mais próximo de um valor entre 1,3 e 2 do número total de internações, isto é, depois de corrigida a ausência de notificação da rede privada. A comparação das PNA corrobora a hipótese de que a taxa de aborto permanece estável, mas as internações se tornaram menos frequentes (DINIZ, et al, 655-656)

Há um receio das mulheres que abortam no Brasil, através de métodos caseiros e $a$ priori não amparadas pelas excludentes, em procurar serviços de saúde após o procedimento ou na eventualidade de alguma complicação intermitente. No Estado de São Paulo há 30 mulheres sendo processadas pelo crime de auto aborto (art. 124 do Código Penal), nos quais os denunciantes são os próprios médicos, violando regulamentação de sigilo do Conselho Federal de Medicina, no Código de Ética Médica, que expressamente veda a exposição do paciente a situação que possa lhe gerar processo penal, nos termos de seu art. 73, Parágrafo Único ${ }^{21}$.

\footnotetext{
${ }^{19}$ Relatório completo da pesquisa, com explicação metodológica da apuração de dados e demais informações disponível em < http://www.scielo.br/pdf/csc/v21n2/1413-8123-csc-21-02-0563.pdf >.Acesso em 10 de Maio de 2018.

${ }^{20}$ Relatório da pesquisa disponível em < http://www.scielo.br/pdf/csc/v22n2/1413-8123-csc-22-02-0653.pdf > Acesso em 08 de Janeiro de 2018.

${ }^{21}$ Em sua literalidade, no Código de Ética Médica:

"Art. 73. Revelar fato de que tenha conhecimento em virtude do exercício de sua profissão, salvo por motivo justo, dever legal ou consentimento, por escrito, do paciente.

Parágrafo único. Permanece essa proibição: a) mesmo que o fato seja de conhecimento público ou o paciente tenha falecido; b) quando de seu depoimento como testemunha. Nessa hipótese, o médico comparecerá perante a autoridade e declarará seu impedimento; c) na investigação de suspeita de crime, o médico estará impedido de revelar segredo que possa expor o paciente a processo penal". [grifo nosso]
} 
Existiam 30 processos tramitando no Estado de São Paulo referentes ao auto aborto, que traça o perfil das mulheres processadas entre 16 e 41 anos, em regra solteira, desempregadas ou em subempregos, pobres na acepção legal, portanto, amparadas pela Defensoria Pública do Estado, que ajuizou Habeas Corpus no Tribunal de Justiça de São Paulo, que veio a reconhecer, em decisão da Desembargadora Kenarik Boujikian, pelo arquivamento dos processos por ilegalidade probatória, haja vista que os denunciantes foram profissionais da saúde que as atenderam em profilaxia. A desembargadora manifesta ainda que compreende pela inconstitucionalidade da tipificação, nos termos do HC 124.306/RJ, porém que penderia quanto ao mérito sobre tal, posto não haver maioria na corte ${ }^{22}$.

$\mathrm{Na}$ Argentina, de contexto sociocultural aproximado ao Brasil quanto à democratização tardia (1983) após período ditatorial militar sangrento, igualmente enfrenta tentativas de discussão de descriminalizar/legalizar o aborto voluntário, fundamentados no fato de que a esfera legislativa constitui um espaço de produção de sentido sobre a subjetividade e os corpos, cuja legislação restritiva implica em campos de dominação e disputa para a imposição de papeis e práticas associadas à sexualidade e que impactam no exercício dos diretos reprodutivos, e naquilo que concerne às mulheres, sobre a autonomia corporal das mesmas (ZICAVO; ASTORINO; SAPOROSI, 2017, p. 1183-1197).

Tal implica que essas mulheres restam desamparadas mesmo em casos de aborto espontâneo e a inassistência em relação a uma necessidade de curetagem e demais cuidados médicos pode vir a causar enfermidades e complicações passíveis de morte.

Mesmo com todo o lastro numérico quanto a dados de que a legalização do aborto é uma medida socialmente adequada e redutora de mortes, como será tratado no item 1.1.2 deste, o Brasil continua violando convenções das quais é signatário por uma tacanheza e misoginia arraigada na legislação.

A preocupação da ala conservadora do cenário do Brasil de 2017 e 2018, esta que ganhou expressividade após o controverso impedimento da Presidenta Dilma Rousseff, em 2016, e que tem promovido retrocessos legais significativos e impopulares, sobretudo no que tange aos direitos fundamentais individuais e sociais, após a sinalização vinda do Supremo Tribunal Federal (HC 124.306/RJ) tendente a desconsiderar o aborto como crime até a $12^{\mathrm{a}}$ semana de gestação, em razão da oportunidade interpretativa, haja vista não haver limitação legal tipificada quanto aos marcos temporais.

Diante dessa decisão, foi acelerada a tramitação da proposta o Projeto de Emenda Constitucional 181/2015, de autoria do ora Senador Aécio Neves (PSDB/MG) que inicialmente prevê a ampliação da licença maternidade em casos de bebês prematuros, mas que teve duas substituições realizadas no texto pelo ora Deputado Jorge Tadeu Mudalen (DEM/SP), que virtualmente seriam aptas a vedar constitucionalmente e tornar a obstrução do acesso ao aborto legal matéria de direitos fundamentais (contrariando explicitamente a Convenção de Belém do Pará, a qual o Brasil é signatário), daí a alcunha de "Cavalo de Troia", inserindo no caput do art. $5^{\circ}$ da Constituição da República a expressão "inviolabilidade do direito à vida desde à concepção" [grifo nosso], bem como no art. $1^{\circ}$, inc. III, ao tratar dos fundamentos da República, passar a constar "dignidade da pessoa humana desde a concepção" [grifo nosso] ${ }^{23}$,estabelecendo

\footnotetext{
Disponível em < http://www.rcem.cfm.org.br/index.php/cem-atual >.Acesso em 22 de Abril de 2018.

${ }^{22}$ Disponível em

https://www.defensoria.sp.def.br/dpesp/Conteudos/Noticias/NoticiaMostra.aspx?idItem=76519\&idPagina=3086

$>$.Acesso em 10 de Maio de 2018.

${ }^{23}$ Significativo simbolicamente a manifestação do ora ocupante da cadeira da Presidência da República, Michel Temer, que após promover a saída da primeira Presidenta eleita (e reeleita), diz que "a vida do nascituro deve prevalecer sobre o desejo da gestante", evidenciando que valora muito mais uma expectativa de vida do que a vida e uma pessoa sujeito de direitos e com personalidade jurídica. Disponível em < http://www1.folha.uol.com.br/colunas/claudiacollucci/2017/04/1872896-vida-do-nascituro-deve-prevalecer-sobredesejo-da-gestante-diz-temer.shtml?loggedpaywall > Acesso em 06 de Janeiro de 2018.
} 
um marco inicial constitucional protetivo e tornando as previsões de excludente de ilicitude do Código Penal (previstas desde 1940) não recepcionadas pela Emenda, demarcando o início jurídico da vida humana.

Declaram os deputados interessados na alteração simplisticamente que há vida desde a concepção, sem recorrer a explicações mais aprofundadas do questionamento filosófico que implica discutir o conceito de vida. Por trás das respostas simples se escondem as intenções não visualizadas no argumento de fácil acesso da proteção e evitação do aborto das outras e a ignorância da realidade fática do controle dos corpos dessas mulheres: se não aceitarem gestar o filho de seus estupradores, deverão correr os riscos da cadeia ou da morte, e àquelas hoje mais protegidas pela lei penal em vigência, que são as menores que sofrem abusos domésticos e silenciam por medo e ignorância até a descoberta através da gestação incestuosa, não restará saída senão a marginalidade legal de seus atos, implicando na segregação social compulsória, como se faz ao gerir os "indesejados".

Essa resposta conservadora a partir de agentes políticos brasileiros é uma tendência que ganha autofalante a partir da equivalência da pauta feminista (como demais causas progressistas) com as pautas da esquerda, e serve de plataforma política e moeda de troca para que estes sujeitos alcancem projeção nesse cenário e se vinculem a uma orientação "pró vida" que tem demonstrado uma recepção popular positiva por inúmeros fatores - desde a crise de representatividade na política tradicional a um cenário econômico deficitário, bem como construções de senso comum arraigadas no imaginário e amplamente exploradas em mídias online de clickbait. O tema também tende a tirar o foco de assuntos relativos a cortes em programas sociais e um caos administrativo de conivência e vinculação à corrupção que afetam estes mesmos agentes.

Como já dito, quando há crises de representatividade, os direitos fundamentais das minorias passam a ser negociados no balcão de direitos dispostos, e o corpo das mulheres passa a ser objeto dessa disposição, que argumentam uma defesa da "vida" em potencial em abstrato como sujeito de direitos, e relegam a segundo plano uma pessoa humana real - a mulher - e sujeita de direito efetivamente.

"Vida" tem-se tornado um conceito lábil, um "signo instável", em termos de Bakhtin (1981), no qual, à sombra de uma correspondência biunívoca entre o significante e o significado, encontram-se múltiplos sentidos. Apenas o contexto e o enunciador outorgam valor ao termo. No entanto, a luta pela "hegemonia" de um significado sobre outro, ou pela legitimidade da enunciação (pela definição do enunciador adequado), provoca contradições e ambiguidades dentro de uma mesma peça discursiva. Bourdieu (1985) afirma que o discurso sobre o objeto fala mais da relação do autor com o objeto do que do objeto em si. Aparentemente, a "vida", tal como aparece nos discursos dos ativistas conservadores religiosos, implica a reprodução biológica por meio da família monogâmica heterossexual, e, a partir daí, é construído o edifício moral que permitirá a perpetuação dessa ordem social. [...] A sacralização da vida refere mais a uma potencialidade do que à vida humana concreta. A vida contida no $z e f^{f 24]}$ é sagrada pelas possibilidades que encerra, não pelo que é. A vida encarnada num adolescente pobre e ladrão não é alvo da mesma preocupação, pois é uma vida concreta que apenas contém seu presente. Daí ser possível pensar que, para os ativistas conservadores religiosos católicos e neopentecostais - e não religiosos, a vida é a vida nua. (ROSTAGNOL, 2016, p. 225-226) [grifos da autora]

Diante dessas circunstâncias, o Judiciário passa a ser um espaço para a possibilidade de discussão do tema no formato que se desenha neste, ou ainda, como expressa Debora Diniz e Anna Cristina G. Vélez (2008, p. 649), que num contexto de pouca cultura e tradição democrática

${ }^{24}$ De acordo com a autora, zefcomo abreviação de zigoto, embrião e feto.

Revista de Direito Brasileira | São Paulo, SP | v. 20 | n. 8 | p. 378-407 |Mai./Ago. 2018 
"a Suprema Corte assume um papel ainda mais preponderante para garantir não apenas a secularização do Estado, mas principalmente que o confronto argumentativo dar-se-á em bases defensáveis e fundamentado na razão pública laica”. Tal tem sido demonstrado em tendência contramajoritária e sinalizado no sentido de compreensão da constitucionalidade da interrupção da gestação, como será aprofundado adiante, mesmo que de modo parcimonioso.

\section{O QUE SIGNIFICA O HC 124.306/RJ}

Historicamente, é importante observar que o aborto torna-se de interesse público no início do século XX, na necessidade de se pensar o desenvolvimento nacional através do controle de natalidade, posto que até então contraceptivos e abortivos eram anunciados, vendidos em farmácias e quando se referiam a "medicamentos para mulheres" escondiam do rótulo os efeitos abortivos, numa relativa tolerância ao assunto - a pílula anticoncepcional ainda não existia e os métodos de controle eram pouco precisos (DEL PRIORE, 2013, 1. 2338).

Durante o Estado Novo, valorizou-se a ideia de coesão social para fortalecer a pátria. Esse apelo implicava a definição de um modelo de família que expurgaria todos os problemas: imoralidade, sensualidade e indolência. A população suspeita de incorrer nesses "delitos" sofria repreensões. O papel da mulher não era na rua, trabalhando, mas em casa, cuidando dos filhos. De todos. Nada de controlar o tamanho das famílias, mas sim de cuidar para que não produzissem casamentos desfeitos, tendo de lidar com suas consequências: alcoolismo, delinquência, marginalidade. Em 1940, o novo Código Penal definia prisão de um a três anos para gestante que abortasse. [...] Apesar dos cuidados legais, poucas mulheres foram punidas por aborto voluntário. A maioria tinha que enfrentar a repreensão social: polícia em casa, depoimentos de parentes e vizinhos, fofocas e humilhações. Acusadas de "amantes" de alguém, esse "alguém", contudo, raramente dava as caras. (DEL PRIORE, 2013, 1. 2339)

Culminou-se que, modernamente, no fim de 2016 manifestou-se ineditamente o Supremo Tribunal Federal, na figura do Ministro Luis Roberto Barroso, seguido pela maioria dos demais, em caso de Habeas Corpus analisado pela corte, no sentido de atribuir uma interpretação constitucional aos dispositivos referentes ao aborto presentes do Código Penal, com a finalidade de considerar fato atípico a realização do aborto até a $12^{\mathrm{a}}$ semana de gestação (usou na decisão o termo "primeiro trimestre"), o que geraria uma nova leitura dos artigos sem necessidade de alteração legal.

Os artigos que referenciam o tema estão entre os artigos 124 a 128 do Código Penal (e lá se encontram desde 1940) tipificando o auto aborto, bem como o aborto realizado por terceiros com e sem consentimento da gestante. $\mathrm{O}$ art. 128 traz as excludentes de ilicitude, como sustenta a doutrina majoritária (vide item 1.1), logo, não se trata de conduta atípica, no chamado aborto terapêutico, cuja gestação apresenta riscos à mulher, bem como em casos de estuproe mais recentemente por decisão jurídica, em caso de anencefalia, como visto previamente.

Não há definição legal para o que seria "aborto", bem como não há marcos legais determinantes do período em que abrange o tipo penal, tratando-se de uma definição em aberto, como também já tratou-se, e a doutrina tradicional compreende que para efeitos criminais seja considerada a interrupção intencional do processo de gravidez com a morte do feto, cujo fundamento para a tipificação reside na garantia constitucional de proteção à vida humana, em que a ideia se encontra reforçada por valores religiosos e existenciais da própria espécie; todavia, questões sociais e de saúde pública, consideravelmente em países periféricos como é o caso brasileiro, uma vez que os auto abortos clandestinos geram mortes e infecções especialmente nas classes sociais de base. 
Também ganhou força questões de proteção de saúde física e psíquica da mulher, do reconhecimento de sua dignidade, livre arbítrio e autonomia (DELMANTO, et al, 2007, p.372), o que tende a ganhar cada vez mais espaço e consideração pela literatura jurídica visto o maior espaço de discussão para questões feministas no campo do Direito, sendo a pauta da legalização do aborto um marco nesse sentido de lutas pela liberdade de disposição e autonomia do próprio corpo.

A discussão aprofunda-se nos marcos temporais quando se diferencia o início da gravidez com o início da vida [viável], haja vista que a garantia constitucional protetiva da vida não a resguarda na condição de direito fundamental absoluto, tendo inclusive previsões de exceções, ao passo que, como já mencionado, os direitos de personalidade civil iniciam-se, de acordo com a legislação vigente, a partir do nascimentocom vida. Se considerado o valor intrínseco da vida, numa vinculação com a santidade e milagre da geração humana, e não a respeito dos interesses ou direitos do feto (que inexistentes) como leciona Dworkin, restariam impedidos inclusive manipulações genéticas de fecundação laboratorial e descarte de embriões para uso científico, que tecnicamente se enquadraria no tipo. Em todo caso, tal consideração revelaria o descaso pela vida e personalidade e interesses da mulher como indivíduo, uma vez que a proteção jurídica dada à gestação desde a concepção, como se pretende, ou mesmo no modo previsto no Brasil, é uma hipótese que desconsidera todos os planos da mulher e a vincula a uma tutela estatal - como um útero a serviço do Estado - pois pretende encerrar na "vida" abstratamente considerada como sujeito de direitos, quando de fato as pessoas - incluindo-se as mulheres... vale lembrar - são sujeitos de direito.

Para fins científicos vigentes numa interpretação com respaldo normativo na Lei n. 9.434/1997, que compreende o óbito como "morte encefálica", portanto o seu oposto seria início da vida a partir do momento em que o feto possui impulsos cerebrais (DELMANTO et al, 2007, p.373), como já se explorou supra (DWORKIN, 2003, p.22).

Justamente nesse sentido de interpretação temporal da norma penal em branco foi que deu-se a interpretação filtrada constitucionalmente do Ministro Barroso, no Habeas Corpus 124.306/RJ, judicialmente um marco importante no debate e no reconhecimento da pauta, e que na sequência se analisa alguns de seus principais argumentos pela descriminalização do aborto, ao colocar em perspectiva e levar em consideração osdireitos sexuais e reprodutivos da mulher, sua autonomia como gestante, bem como sua integridade física e psíquica ${ }^{25}$.

(a) A decisão considerou o papel do Estado em situações moralmente controversas, como ocorre com o aborto, ao manifestar-se no sentido de que

Em temas moralmente divisivos, o papel adequado do Estado não é tomar partido e impor uma visão, mas permitir que as mulheres façam sua escolha de forma autônoma. O Estado precisa estar do lado de quem deseja ter o filho. O Estado precisa estar do lado de quem não deseja - geralmente porque não pode - ter o filho. Em suma: por ter o dever de estar dos dois lados, o Estado não pode escolher um. [...] A reprovação moral do aborto por grupos religiosos ou por quem quer que seja é perfeitamente legítima. Todos têm o direito de se expressar e de defender dogmas, valores e convicções. O que refoge à razão pública é a possibilidade de um dos lados, em um tema eticamente controvertido, criminalizar a posição do outro. [grifo nosso] (STF. HC 124.306/RJ)

Nesse sentido, complementarmente, importa observar ao que se presta tal tutela do modo como posto, em que penalizar o aborto cumpre função anacrônica de perpetuação de culpa religiosa e moral, como medida de desqualificação feminina e punibilização da liberdade sexual, 
fomentando culturalmente a postura de que o corpo da mulher não é lugar de posicionamento integral de si que o posicionamento político que emana é a partir da disposição do Estado que o tutela através de uma legislação construída e sistematizada para o domínio feminino a partir da "normalidade" de gênero masculina. A Constituição declara o compromisso com o ideal abstrato que constitui um "governo justo e igualitário". Na cultura política ocidental, em termos gerais, o direito à autonomia procriadora é característica da dignidade humana individual, e assim defronta-se com as questões mais fundamentais sobre o significado e o valor de suas próprias vidas e escolhas, em busca de respostas para suas próprias consciências e convicções (DENORA; ALVES, 2016).

Nesse sentido, ao tratar de razão pública, Débora Diniz e Anna Cristina G. Vélez (2008, p. 651) explicam que a razão pública deve ser não apenas um instrumento argumentativo para os juízes e os procuradores em sessões de julgamento, mas também uma garantia para a estabilidade democrática de um Estado constitucional. E o compromisso com a mesma em assuntos que versem sobre o aborto é representada pela razoabilidade argumentativa e com a neutralidade confessional do Estado devendo ser a linguagem do Estado exercido através do Supremo, e um instrumento de controle democrático de seus posicionamentos.

(b) Ao realizar a filtragem constitucional dentro da ponderação dos conflitos aparentes de direitos fundamentais em tutela, bem como naquilo que é muito caro aos movimentos feministas em fomento de igualdade material de gênero, manifestou-se no sentido de que

A criminalização é incompatível com os seguintes direitos fundamentais: os direitos sexuais e reprodutivos da mulher, que não pode ser obrigada pelo Estado a manter uma gestação indesejada; a autonomia da mulher, que deve conservar o direito de fazer suas escolhas existenciais; a integridade física e psíquica da gestante, que é quem sofre, no seu corpo e no seu psiquismo, os efeitos da gravidez; e a igualdade da mulher, já que homens não engravidam e, portanto, a equiparação plena de gênero depende de se respeitar a vontade da mulher nessa matéria. [...] A criminalização viola, também, os direitos sexuais e reprodutivos da mulher, que incluem o direito de toda mulher de decidir sobre se e quando deseja ter filhos, sem discriminação, coerção e violência, bem como de obter o maior grau possível de saúde sexual e reprodutiva [...] [Há] uma visão idealizada em torno da experiência da maternidade, que, na prática, pode constituir um fardo para algumas mulheres. Na medida em que é a mulher que suporta o ônus integral da gravidez, e que o homem não engravida, somente haverá igualdade plena se a ela for reconhecido o direito de decidir acerca da sua manutenção ou não. [grifo nosso] (STF. HC 124.306/RJ)

É muito relevante em representatividade (sobretudo em tempos de mitigação dos direitos sociais de minorias) a interpretação com enfoque na igualdade na diferença, que visa estabelecer parâmetros materiais de equivalência, ao considerar inclusive o papel social da mulher no exercício do ser e de ser mulher em seu corpo ("a mulher que suporta o ônus integral da gravidez") integrando e respeitando sua decisão e autonomia.

As relações sociais e jurídicas são complexas e o Estado já reconheceu formalmente questões fundamentais para todos, sem exceção. Portanto também inclui a mulher como sujeito de direitos quanto o homem e necessita de representatividade política e organizacional para a satisfação de seus interesses específicos devido a sua particular condição num ambiente democrático. Para novas situações juridicamente sofisticadas não se pode dar soluções velhas e simplistas. Em suma: não se pode continuar criminalizando o diverso e sua condição.

Em análise histórico-evolutiva das conquistas das mulheres, evidentemente que se vislumbra a partir do momento presente uma inclusão expressiva em esferas de direitos e participação social. Todavia essa inclusão é acompanhada de violências, simbólicas e/ou fáticas, 
que perpetuam condições desiguais, tanto em direitos como reflexos socioculturais (DENORA; ALVES, 2016).

As sociedades sexistas organizaram o ordenamento jurídico de modo a garantir o establishment. As mulheres sofreram uma espécie de capitis diminutio, sendo que passaram a ser consideradas à margem do direito, da mesma forma que os presos, e aqueles que têm desenvolvimento mental incompleto, quer sejam crianças, quer sejam deficientes mentais. Mesmo as leis mais democráticas mantiveram as mulheres nesse patamar. (BREGA FILHO; ALVES, 2013)

E considerar os aspectos específicos pela condição enquanto mulher é representativo mesmo como inclusão no fluxo revolucionário democratizante de uma sociedade que objetiva caminhar na percepção do outro na condição de igual e livre.

(c) A decisão também não foi silente quanto ao recorte das funções reais a que se presta legislação proibitiva em sede de direito penal, nesse caso segregacionista na interseccionalidade de gênero, raça e classe, que ao tentar dar uma resposta criminal inócua para um problema social, termina por gerar novos problemas sociais, como na saúde pública, e rompe declaradamente com a hipocrisia negatória da existência de metarregras e práticas sociais as quais o Estado não alcança pela sua estrutura formal legislativa, e que ignorar a clandestinidade da prática equivale a mortes e esterilizações de mulheres, ao manifestar que negar juridicamente uma realidade social não faz com que ela desapareça:

Ao se afirmar a incompatibilidade da criminalização com a Constituição, não se está a fazer a defesa da disseminação do procedimento. Pelo contrário, o que se pretende é que ele seja raro e seguro [...] A tipificação penal produz também discriminação social, já que prejudica, de forma desproporcional, as mulheres pobres, que não têm acesso a médicos e clínicas particulares, nem podem se valer do sistema público de saúde para realizar o procedimento abortivo. Por meio da criminalização, o Estado retira da mulher a possibilidade de submissão a um procedimento médico seguro. Não raro, mulheres pobres precisam recorrer a clínicas clandestinas sem qualquer infraestrutura médica ou a procedimentos precários e primitivos, que lhes oferecem elevados riscos de lesões, mutilações e óbito. [...] O que a criminalização de fato afeta é a quantidade de abortos seguros e, consequentemente, o número de mulheres que têm complicações de saúde ou que morrem devido à realização do procedimento. Trata-se de um grave problema de saúde pública, oficialmente reconhecido. [Grifo nosso] (STF. HC 124.306/RJ)

Ao aprofundar o anseio de um Estado efetivo e inclusivo, mostra o que já se discute dentro das criminologias críticas sobre o uso do direito penal como promotor de desigualdade, encarcerador da pobreza e da baixa escolaridade, por um recorte de classe muito claro, que serve para fins declarados (reinserção social do criminoso, reeducação intensiva pela pena, resposta à sociedade como fim educativo indireto), e para fins não declarados, porque "escondidos" na fachada das declarações oficiais do poder estatal, reproduzidos extensivamente de forma a banalização criminal e a partir da criação da falsa sensação de segurança através do Direito Penal.

Esses fins não declarados importam no tema do aborto, porque utilizam o Direito Penal como meio de legitimação de discurso não assumido e não revelado, segregador de classe e promotor de estigmatização do diferente. Neste caso, da mulher e da sexualidade feminina, e sobretudo da mulher pobre (e em maioria negra), que por sua condição dependente das políticas de saúde pública do Estado e pela pouca ou nenhuma instrução/informação adequada a meios contraceptivos (DENORA; ALVES, 2016).

O direito penal é patriarcal, patrimonial e promotor de desigualdades, age para justificar questões de classe e uma moral burguesa de submissão e exclusão/negação da mulher, da 
sexualidade feminina, e através dele perpetua os fundamentos a que veio. Cuidar de igualdade em condições desiguais - de classe e de gênero, aqui enfatizado - é cuidar da necessidade de implementação de ações afirmativas a fim de estabelecer condições equânimes de realizações, e não simplesmente satisfazer as necessidades sociais através de resposta criminal como política criminal de Estado.

(d) E por fim, no que se refere a análise ponderativa de estabelecer socialmente um regime de interesses a quem proteger - que ao fim e de pronto, haverá uma difícil escolha a ser feita, nos limites das liberdades individuais de cada consciência e um aparente conflito de direitos fundamentais e interesses - e qual a forma de tutela mais inclusiva destes interesses, em que manifesta o ministro que "É preciso verificar se as restrições aos direitos fundamentais das mulheres decorrentes da criminalização são ou não compensadas pela proteção à vida do feto". Sarmento observa que o tema do aborto envolve a autonomia reprodutiva da mulher, com fundamento constitucional na liberdade e privacidade, cuja proteção constitucional dada à vida pré-natal deve ser ponderada aos direitos humanos da gestante, bem como sua autonomia, e uma resposta criminal não é satisfativa ética e constitucionalmente. Manifesta que

O que não parece de todo admissível é negligenciar um dos componentes desta equação, como fez o legislador penal brasileiro, ao ignorar solenemente a autonomia reprodutiva da mulher no tratamento conferido ao aborto. Que isto tenha ocorrido no início da década de 40 do século passado - no contexto de uma sociedade profundamente machista, e num momento político autoritário, em que a liberdade não era devidamente prezada - não é de se admirar. Mas o que não se compreende é a manutenção da mesma equação legislativa em pleno século XXI, num cenário axiológico absolutamente diverso, e sob a égide de uma Constituição que entroniza a liberdade com um dos seus valores máximos. (SARMENTO, 2014, p. 77)

Respeitar os direitos de personalidade da mulher e confiar a ela que possa decidir sobre questões de seu próprio corpo estão na base dos direitos fundamentais no que tange à tutela e garantia não somente de questões igualitárias materiais, mas de liberdade. Não há um direito a vida em abstrato do feto como sujeito de direitos defensável na estrutura de interesses posta diante da filtragem democrática pleiteada como valorativa pelo jus filósofo.

A escolha em vigência pelo Estado ao criminalizar o aborto é a de abandonar essas mulheres, é estar presente apenas como obstáculo muito violento para sua realização enquanto pessoa de direitos e em exercício de direitos. Manter o aborto sob a égide do Direito Penal tão somente exerce punição sobre o corpo da mulher - se não a do cárcere, a punição indireta, que a obriga a buscar meios ilegais para realização do aborto, a colocando em riscos - de saúde a jurídicos - porque a presença criminal do Estado o faz ausente positivamente na realização da plenitude das capacidades dessa mulher.

Mas então a manifestação do Ministro Barroso descriminaliza o aborto no "primeiro trimestre"? Não. Na prática, ele tão somente manifestou seu entendimento descriminalizante interpretativo, com o escopo liberal claramente teorizado a partir de Dworkin, que sabido, tem influência acadêmica no então professor Barroso. É uma persiana que se abre numa atmosfera densa de film noir, mas muitas janelas e portas ainda estão fechadas e em preto e branco sobre o tema.

\section{CONCLUSÕES}

Decidir sobre levar adiante ou não uma gestação indesejada é uma dor solitária cujas lágrimas não podem ser mostradas - o Estado proíbe através da tutela criminal que se manifeste, além do peso da moralidade vigente que criminaliza o ato sexual para a mulher, que limita a ela a condição compulsória da maternidade ou o flerte com a morte. Um Estado que nega direitos 
básicos preventivos (educação, saúde) e que torna tabu a discussão de gênero e educação sexual nas esferas públicas, presta-se a um fim opressivo de abandono. As mulheres que recorrem ao aborto no Brasil o fazem em regra por desespero, um desespero que se mantém e se perpetua através da dominação masculina que está encalacrada nas estruturas sociais, familiares, legislativas e jurídicas, e que neste caso visa exercer um controle sobre a vida sexual e reprodutiva da mulher, como sinalizamos nesta análise.

Buscou-se revelar neste texto as consequências sociais que a legislação em vigência produz, e que esta (a lei) fora um produto de um tempo que se tornou anacrônico no constitucionalismo moderno, tratando de pontos preliminares importantes no debate, bem como a decisão histórica (e simbólica) que manifestou-se no sentido de uma nova interpretação a esta mesma normatização em vigência, ao passar a considerar o cenário fático numa filtragem constitucional para compreender que, hermeneuticamente, realizar aborto no primeiro trimestre de gestação é fato atípico por assim responder aos interesses fundamentais da mulher, no uso do Estado em intervenção mínima da esfera individual de direitos e proteção máxima de interesses sociais como a saúde pública.

Por óbvio que os tempos demonstram que tal leitura não será facilmente implementada. O legislativo brasileiro, desde a redemocratização, nunca foi tão reacionário, e neste sentido, além da PEC "Cavalo de Troia", a PLS 461/2016, que determina que o aborto deve ser considerado como crime em qualquer fase da gravidez (Sen. Pastor Valadares/PDT-RO) ${ }^{26}$, veio como resposta à decisão analisada, além de discursos manifestos no sentido de passar a considerar punível também os abortos em caso de estupro; outros parlamentares visam tornar caso de polícia mesmo os abortos espontâneos - afinal, a palavra da mulher é sempre colocada em dúvida. Por outro lado, no setor progressista, há o PL 882/2015 (Dep. Jean Wyllys/PSOL$\mathrm{RJ})^{27}$ com o objetivo de regulamentação do procedimento de aborto em consonância com as legislações europeias e uruguaia, que viabilizam um suporte psicológico e médico para a mulher que busca o procedimento, e se por fim decidir por efetivamente interromper a gestação, o fará de modo sanitariamente adequado. Nesse sentido, a experiência uruguaia é bastante feliz, em que após legalizar o aborto e oferecer uma estrutura de auxílio, conseguiu reduzir as taxas de abortos realizados $^{28}$, e zerar as mortes por complicações no procedimento ${ }^{29}$. O que demonstra o papel inclusivo da norma e que a resposta criminalizante dada no Brasil não cumpre seu papel social como imaginado.

Rever conceitos e determinações legais sobre o aborto por uma filtragem constitucional é demonstrar respeito pela esfera de direitos da personalidade da mulher e seus interesses enquanto sujeito de direito, e não meramente em suas funções reprodutivas, respeitando sua dimensão moral em dignidade humana ao permitir que decisões sobre si em esfera de individualidade sejam tomadas de modo que o Estado, em seu papel garantidor, permita o exercício de liberdades sem que seja ele mesmo um óbice de realização enquanto sujeito social. Respeitar a decisão do outro sobre si a partir de sua própria realidade revela as chances de concretização de uma democracia inclusiva que oportuniza a todos pluralidade ideológica e religiosa, além de minimizar agravamentos sociais advindos do uso indiscriminado do direito penal como resposta a direitos sociais.

\footnotetext{
${ }^{26}$ Íntegra do projeto em <http://www25.senado.leg.br/web/atividade/materias/-/materia/127776> Acesso em 13 de Agosto de 2017.

27 Íntegra do projeto em <http://www.camara.gov.br/proposicoesWeb/fichadetramitacao?idProposicao=1050889> Acesso em 13 de Agosto de 2017.

${ }^{28}$ De acordo com dados de $2014<$ https://www.terra.com.br/noticias/mundo/america-latina/uruguai-apos-legalizacaodesistencia-de-abortos-sobe-30,2e4163764976c410VgnCLD200000b1bf46d0RCRD.html> Acesso em 13 de Agosto de 2017.

${ }^{29}$ De acordo com os dados colhidos no período após 2 anos da legalização <http://www.plan-eval.com/blog/?p=407> Acesso em 13 de Agosto de 2017.
}

Revista de Direito Brasileira | São Paulo, SP | v. 20 | n. 8 | p. 378-407 |Mai./Ago. 2018 


\section{REFERÊNCIAS}

BIROLI, Flávia; MIGUEL, Luis Felipe (orgs.). Aborto e Democracia. São Paulo: Alameda, 2016.

. Teoria Política e Feminismo: abordagens brasileiras. E-book Kindle (4946 locations). Vinhedo: Editora Horizonte, 2012.

BIROLI, Flávia; MIGUEL, Luis Felipe. Feminismo e política. São Paulo: Boitempo, 2014.

BITENCOURT, Cezar Roberto. Tratado de Direito Penal: Parte Especial, vol. 2. $6^{\mathrm{a}}$ ed. revista e atualizada. São Paulo: Saraiva, 2007.

. Tratado de Direito Penal: Parte Especial, vol. 2. Crimes Contra a Pessoa. $18^{\mathrm{a}}$ ed. São Paulo: Saraiva Educação, 2007.

BREGA FILHO, Vladimir; ALVES, Fernando de Brito. O Direito das Mulheres: Uma Abordagem Crítica. Argumenta Journal Law, Jacarezinho - PR, n. 10, p. 131-142, fev. 2013. ISSN 2317-3882. Disponível em: <http://seer.uenp.edu.br/index.php/argumenta/article/view/130/130>. Acesso em 26 de Junho de 2017.

Contribuição da Secretaria Especial de Políticas para as Mulheres para as Conferências Estaduais. Documento Base. I Conferência Nacional de Políticas para as Mulheres. Brasília: Secretaria Especial de Políticas para as Mulheres, 2004. Disponível para download em PDF em <www.observatoriodegenero.gov.br/>. Acesso em 01 de Maio de 2018.

DA ROCHA, Maria Isabel Baltar. A Questão do Aborto no Brasil: o Debate no Congresso. ESTUDOS FEMINISTAS, p.381-398, 1996. Disponível em: < https://periodicos.ufsc.br/index.php/ref/article/viewFile/16809/15400 > Acesso em 23 Setembro de 2016.

DELMANTO, Celso [et al]. Código Penal Comentado. $7^{\mathrm{a}}$ ed. atualizada e ampliada Rio de Janeiro: Renovar, 2007.

DEL PRIORE, Mary. Histórias Íntimas: Sexualidade e Erotismo da História do Brasil. São Paulo: Editora Planeta do Brasil, 2011. E-Book Kindle (4193 locations), 2011.

- Conversas e Histórias de Mulher. São Paulo: Planeta, 2013. E-Book Kindle (4562 locations), 2013.

DENORA, Emmanuella Magro; ALVES, Fernando de Brito. Legalização do Aborto: Medida Democrática e Inclusiva de Direitos das Mulheres. Gênero, sexualidades e direito III. CONPEDI, $2016 . \quad$ Disponível em < https://www.conpedi.org.br/publicacoes/02q8agmu/01018151/7wjg31815CC77L98.pdf > Acesso em 13 de Agosto de 2017.

DINIZ, Debora. A Condição Feminina no País dos Brucutus. Palestra proferida no Centro Brasileiro de Estudos Constitucionais (CBEC). UniCEUB: Brasília, 2016. Disponível em < https://www.youtube.com/watch?v=tTeawUReiZg >. Acesso em 10 de Janeiro de 2018. 
- Objeção de Consciência e Aborto: Direitos e Deveres dos Médicos na Saúde Pública. Rev. Saúde Pública [online]. 2011, vol. 45, n. 5, pp.981-985. Epub July 29, 2011. ISSN 00348910. Disponível em < http://dx.doi.org/10.1590/S0034-89102011005000047 >. Acesso em 11 de Maio de 2018.

DINIZ, Debora; MEDEIROS, Marcelo. Aborto no Brasil: Uma pesquisa domiciliar com técnica de urna, 2010; Disponível em < http://www.apublica.org/wpcontent/uploads/2013/09/PNA.pdf>. Acesso em 20 de Maio de 2016.

DINIZ, Debora; MEDEIROS, Marcelo; MADEIRO, Alberto. Pesquisa Nacional de Aborto 2016. p. 653 a 660. Ciência \& Saúde Coletiva, 2017. Disponível em < http://www.scielo.br/pdf/csc/v22n2/1413-8123-csc-22-02-0653.pdf >. Acesso em 08n de Janeiro de 2018.

DINIZ, Debora; VÉLEZ, Anna Cristina Gonzalez. Aborto na Suprema Corte: O Caso da Anencefalia no Brasil. Revista Estudos Feministas, Florianópolis, v. 16, n. 2, p. 647-652, maio 2008. ISSN 1806-9584. Disponível em https://periodicos.ufsc.br/index.php/ref/article/view/S0104-026X2008000200019/8797 >. Acesso em 26 de Abril 2018.

DWORKIN, Ronald. Domínio da Vida: Aborto, Eutanásia e Liberdades Individuais. São Paulo: Martins Fontes, 2003.

II Plano Nacional de Políticas para as Mulheres. Brasília: Secretaria Especial de Políticas para as Mulheres, 2008. Disponível em http://portal.mec.gov.br/dmdocuments/planonacional_politicamulheres.pdf > Acesso em 01 de Maio de 2018.

KRAEMER, Heinrich; SPRENGER, James. O Martelo das Feiticeiras. $3^{\mathrm{a}}$ edição. Rio de Janeiro: BestBolso, 2016

LOMBroso, Cesare; FERRERO, Guglielmo. La Donna Delinquente: La Prostituta e La Donna Normale. Torino: Fratelli Bocca Editori, 1903

LUNA, Naara. Aborto no Congresso Nacional: o enfrentamento de atores religiosos e feministas em um Estado laico. Rev. Bras. Ciênc. Polít., Brasília , n. 14, p. 83-109, Aug. 2014. Disponível em < http://www.scielo.br/scielo.php?script=sci_arttext\&pid=S0103$33522014000200083 \& \operatorname{lng}=$ en\&nrm=iso >. Acesso em 11 de Maio de 2018.

Morte por aborto clandestino na imprensa: Jandira, Elizângela e Operação Herodes. Revista Estudos Feministas, Florianópolis, v. 25, n. 3, p. 1159-1181, out. 2017. ISSN 1806-9584. Disponível em < https://periodicos.ufsc.br/index.php/ref/article/view/40845/35165 >. Acesso em 26 de Abril de 2018.

O Direito à Vida no Contexto do Aborto e da Pesquisa com Células-tronco Embrionárias: Disputas de Agentes e Valores Religiosos em um Estado Laico. Relig. soc., Rio de Janeiro, $\quad$ v. 33, n. 1, p. 71-97, 2013. Disponível em < http://www.scielo.br/scielo.php?script=sci_arttext\&pid=S0100$85872013000100005 \& \operatorname{lng}=$ en\&nrm=iso $>$. Acesso em 11 de Maio de 2018. 
MADEIRO, Alberto Pereira; DINIZ, Debora. Serviços de Aborto Legal no Brasil - um estudo nacional. Revista Ciência \& Saúde Coletiva, Rio de Janeiro, v. 21, n. 2, p. 563-572, 2016. Disponível em < http://www.scielo.br/pdf/csc/v21n2/1413-8123-csc-21-02-0563.pdf >. Acesso em 06 de Maio de 2018.

MANTOVANI, Denise Maria. O Aborto e as Eleições de 2010: O papel do Jornalismo da Definição dos Discursos Conservadores. p.189-216. In: BIROLI, Flávia; \& MIGUEL, Luis Felipe (orgs.). Aborto e Democracia. São Paulo: Alameda, 2016.

MIGUEL, Luis Felipe; BIROLI, Flávia; \& MARIANO, Rayani. O Debate Sobre o Aborto na Câmara dos Deputados, de 1990 a 2014. p. 128 - 154. In: BIROLI, Flávia; \& MIGUEL, Luis Felipe (orgs.). Aborto e Democracia. São Paulo: Alameda, 2016.

PIRES, Teresinha Inês Teles. Direito ao Aborto, Democracia e Constituição. Curitiba: Juruá, 2016.

PRADO, Danda. O Que é Aborto. São Paulo: Abril Cultural/Brasiliense, 1985.

PRADO, Luiz Regis. Curso de Direito Penal Brasileiro - v. 2. $4^{\mathrm{a}}$ ed. São Paulo: Revista dos Tribunais, 2005.

. Curso de Direito Penal Brasileiro - v. 2. $11^{\mathrm{a}}$ ed. revista, atualizada e ampliada. São Paulo: Revista dos Tribunais, 2013.

. Curso de Direito Penal Brasileiro - v. II. $16^{\mathrm{a}}$ ed. revista, atualizada e ampliada (a partir da $11^{a}$ ed.). São Paulo: Thomson Reuters, 2018.

ROSTAGNOL, Susana. As Vicissitudes da Lei da Interrupção Voluntária da Gravidez no Uruguai. p. 217 a 237. In: BIROLI, Flávia; \& MIGUEL, Luis Felipe (orgs.). Aborto e Democracia. São Paulo: Alameda, 2016.

SARMENTO, Daniel. Legalização do Aborto e Constituição. Revista de Direito Administrativo, v. 240, p. 43-82, 2014. $\quad$ Disponível em: http://bibliotecadigital.fgv.br/ojs/index.php/rda/article/download/43619/44696 > Acesso em 23 de Setembro de 2016.

ZAFFARONI, Eugenio Raúl. El Discurso Feminista y el Poder Punitivo. p. 47-84. In: PIERANGELI, José Henrique (coord.). Direito Criminal. Belo Horizonte: Del Rey, 2001.

ZICAVO, Eugenia; ASTORINO, Julieta; SAPOROSI, Lucas. "Leyes que son cuerpo/cuerpos que son leyes": proyectos de ley de aborto en Argentina. Revista Estudos Feministas, Florianópolis, v. 25, n. 3, p. 1183-1197, out. 2017. ISSN 1806-9584. Disponível em: < https://periodicos.ufsc.br/index.php/ref/article/view/42350/35203 >. Acesso em 26 de Abril de 2018.

WEIGERT, Mariana de Assis Brasil e. Aulas online, no curso Introdução à Criminologia Feminista: Criminosas, Loucas e Vítimas. Escola Passagens, 2017.Conteúdo Pago. Disponível em < https://www.udemy.com/introducao-a-criminologia-feminista/learn/v4/overview > Acesso em 03 de Janeiro de 2018. 